\title{
Data Compilation Task Report for the Source Investigation of the 300-FF-1 Operable Unit Phase I Remedial Investigation
}

\author{
J.S. Young \\ R. M. Fruland \\ J. S. Fruchter
}

February 1990

Prepared for the U.S. Department of Energy under Contract DE-AC06-76RLO 1830

Pacific Northwest Laboratory

Operated for the U.S. Department of Energy

by Battelle Memorial Institute

\section{* Battelle}
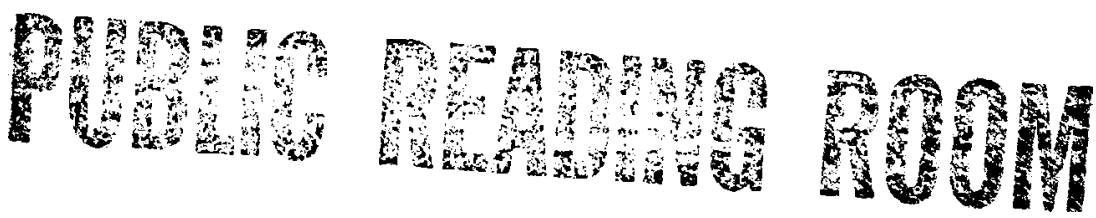


\section{DISCLAIMER}

This report was prepared as an account of work sponsored by an agency of the United States Government. Neither the United States Government nor any agency thereof, nor Battelle Memorial Institute, nor any of their employees, makes any warranty, expressed or implied, or assumes any legal liability or responsibility for the accuracy, completeness, or usefulness of any information, apparatus, product, or process disclosed, or represents that its use would not infringe privately owned rights. Reference herein to any specific commercial product, process, or service by trade name, trademark, manufacturer, or otherwise, does not necessarily constitute or imply its endorsement, recommendation, or favoring by the United States Government of any agency thereof, or Battelle Memorial Institute. The views and opinions of authors expressed herein do not necessarily state or reflect those of the United States Government or any agency thereof.

\section{PACIFIC NORTHWEST LABORATORY operated by BATTELLE MEMORIAL INSTITUTE for the UNITED STATES DEPARTMENT OF ENERGY under Contract DE-AC06-76RLO 1830}

Printed in the United States of America

Available to DOE and DOE contractors from the Office of Scientific and Technical Information, P.O. Box 62, Oak Ridge, TN 37831; prices available from (615) 576-6401. FTS 626-6401.

Available to the public from the National Technical Information Service, U.S. Department of Commerce, 5285 Port Royal Rd., Springfield, VA 22161.

NTIS Price Codes, Microfiche A01

Printed Copy

\begin{tabular}{cr}
\hline Price Code & Page Range \\
\hline A02 & $1-10$ \\
A03 & $11-50$ \\
A04 & $\mathbf{5 1 - 7 5}$ \\
A05 & $76-100$ \\
A06 & $101-125$ \\
A07 & $126-150$ \\
A08 & $151-175$ \\
A09 & $176-200$ \\
A10 & $201-225$ \\
A II & $226-250$ \\
A12 & $251-275$ \\
A13 & $276-300$ \\
A14 & $301-325$
\end{tabular}

\begin{tabular}{cc}
\hline Price Code & Page Range \\
\hline A15 & $326-350$ \\
A16 & $351-375$ \\
A17 & $376-400$ \\
A18 & $401-425$ \\
A19 & $426-450$ \\
A20 & $451-475$ \\
A21 & $476-500$ \\
A22 & $501-525$ \\
A23 & $526-550$ \\
A24 & $551-575$ \\
A25 & $576-600$ \\
A99 & $601-$ U
\end{tabular}


PNL-7241

UC -402

DATA COMPILATION TASK REPORT

FOR THE SOURCE INVESTIGATION

OF THE 300-FF-1 OPERABLE UNIT

PHASE I REMEDIAL INVESTIGATION
J. S. Young
R. M. Fruland
J. S. Fruchter

February 1990

Prepared for

the U.S. Department of Energy

under Contract DE-AC06-76RLO 1830

Pacific Northwest Laboratory

Richland, Washington 99352 


\section{$\underline{\text { SUMMARY }}$}

This report provides additional information on facility and waste characteristics for the 300-FF-1 operable unit. The additional information gathered and reported includes the following:

- meetings and on-site visits with current and past personnel having knowledge of operations in the operable unit

- a more precise determination of the location of the Process Sewer lines and Retired Radioactive Liquid Waste Sewer

- a better understanding of the phosphoric acid spill at the 340 Complex

- a search for engineering plans and environmental reports related to the operable unit.

As a result of this data-gathering effort, recommendations for further investigation are the following:

- characterization of the 307 Trenches to determine the origin of an underlying uranium $\mathrm{pl}$ ume in the groundwater

- more extensive sampling of near-surface and dike sediments in the North and South Process Ponds to better define the extent of horizontal contamination

- detection of possible leaks in the abandoned Radioactive Waste Sewer by either electromagnetic induction or remote television camera inspection techniques. 


\section{CONTENTS}

SUMMARY

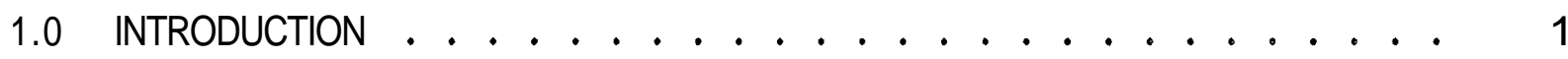

1.1 PRELIMINARY ASSESSMENT/SITE INSPECTION DATA . . . . . . 1

2.0 INTERVIEWS WITH KNOWLEDGEABLE PERSONNEL . . . . . . . . 5

3.0 SOURCEDATACOMPILATION . . . . . . . . . . . . 7

3.1300 AREA SENER SYSTEMS . . . . . . . . . . . 7

3.1.1 Basic Sewer System . . . . . . . . . . 7

3.1.2 Process Sewer Controls ........... 9

3.2 RETIREDSEWERSYSTEMS. . . . . . . . . . . . . . . 10

3.2.1 Retired Process Sewer System . . . . . . . 10

3.3 RETIRED RADIOACTIVE WASTE SEMR LINE . . . . . . . . 15

3.4 UNPLANNED RELEASES AND SPILLS . . . . . . . . . . 18

3.4 UPR-300-1 . . . . . . . . . . . . . 18

3.4.2 UPR-300-2 ........................ 20

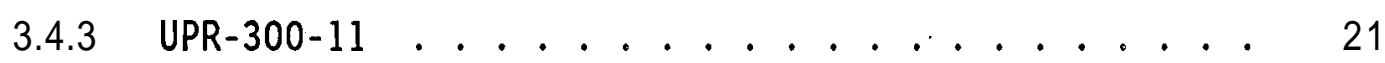

3.4.4 Phosphoric Acid Spill . . . . . . . . . . 21

3.4.5 Other Spills and Releases Near the 340 Complex . . . 22

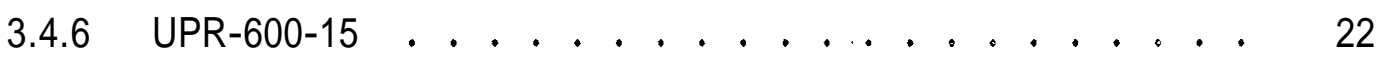

3.5 OTHER FACILITIES . . . . . . . . . . . . . . 22

3.5 .1 Burial Ground №. 4 . . . . . . . . . . 22

3.5.2 Burial Ground No. 5 . . . . . . . . . . . 23

3.5.3 Process Trenches .............. . . 23

4.0 CONCLUSIONS AND RECOMMENDATIONS . . . . . . . . . . . . . 27

4.1 IDENTIFICATION OF THE SOURCE OF THE URANIUM PLUME IN GROUNDWATER BENEATH THE 300-FF-1 OPERABLE UNIT . . . . . . 
4.2 SEDIMENT ANALYSES . . . . . . . . . . . . . . . . . . . . 28

4.3 PHOSPHORIC ACID SPILL . . . . . . . . . . . . . . . . 28

4.4 ALTERNATIVES TO THE TRACER GAS SURVEY OF THE RETIRED

RADIOACTIVE LIQUID WASTE SEWER . . . . . . . . . . . . . '

5.0 REFERENCES ............................. 31 


\section{FIGURES}

1 The 300-FF-1 Operable Unit . . . . . . . . . . . . . 2

2 Schematic of the 300 Area Basic Sewer System . . . . . . . . . . 7

3 The Retired Radioactive Liquid Waste Sewer . . . . . . . . . . . . 17

4 The Bronze Monument Marking a Cleanout of the Abandoned Radioactive Liquid Waste Sewer . . . . . . . . . . . . 19

\section{$\underline{\text { TABLES }}$}

1 Facilities in the $300-F F-1$ Operable Unit That Require Further Remedial Investigation............. 3

2 Facilities in the 300-FF-1 Operable Unit That Do Not Require Further Remedial Investigation . . . . . . . . . . 4

3 Approximate Coordinates of Cleanouts A through K of Retired Radioactive Liquid Waste Sewer . . . . . . . . . . 20

4 Inventory of Radionuclides and Volume of Contaminated Soil Beneath the Corroded 307 Basin Transfer Lines . . . . . . . . . 21

5 Estimates of Chemicals Discharged to the Process Trenches.. ................... 


\subsection{INTRODUCTION}

The 300-FF-1 operable unit (Figure 1) has been defined under the direction of U.S. Department of Energy (DOE) orders based on the Comprehensive Environmental Response, Compensation and Liability Act (CERCLA) and U.S. Environmental Protection Agency (EPA) methodology. Although the process by which inactive waste sites will be remediated has begun, the current operation of many facilities on the Hanford Site is a complicating factor that will continue and must be considered as the CERCLA effort goes forth.

The purpose of this report is to provide additional information on facility and waste characteristics for the $300-F F-1$ operable unit that was not available when the draft work plan (DOE 1989a) was written.

Specifically, the additional information gathered and reported includes the fol lowing:

- meetings and on-site visits with current and past personnel having knowledge of operations in the operable unit

- a more precise determination of the location of the Process Sewer lines and Retired Radioactive Liquid Waste Sewer

- a better understanding of the phosphoric acid spill at the 340 Complex

- a search for other engineering plans and environmental reports related to the operable unit that were not referenced in the draft work pl an (DOE 1989a).

\subsection{PRELIMINARY ASSESSMENT/SITE INSPECTION DATA}

Much information on facility and waste characteristics for the 300-FF-1 operable unit is available from the preliminary assessment/site inspection work. At this point, only selected 300-FF-1 waste transfer, storage, and disposal facilities are targeted for direct characterization during the current remedial investigation. Several of the facilities handled only nonhazardous waste, some have no documented releases of hazardous substances, and certain facilities can be effectively combined to focus the investigation. 


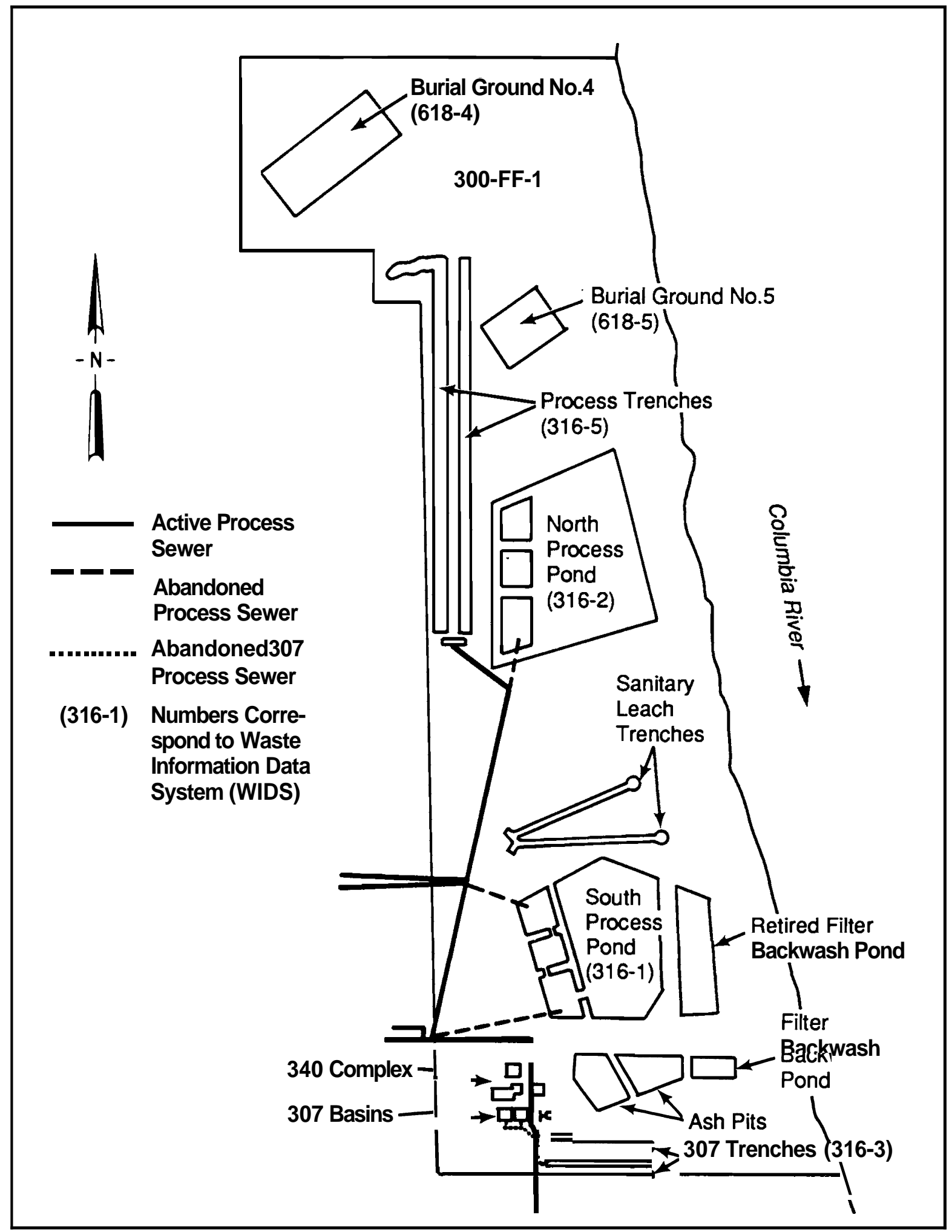

FIGURE 1. The 300-FF-1 Operable Unit 
The Hanford Inactive Surveillance System (HISS data base) contains information for all sites within the 300-FF-1 operable unit, except for the Sanitary Sewer, the Retired Filter Backwash Pond, and the Retired and Current Radioactive Liquid Waste Sewers. Stenner et al. (1988) include the same data concerning the 300 Area inactive waste disposal sites. The four liquid effluent disposal sites within the 300 Area [North and South Process Ponds (316-2 and 316-1), 307 Trenches (316-3), and Process Trenches (316-5); see Figure 1] received both radioactive wastes and chemicals from process and laboratory wastes, along with large volumes of liquids. These are considered to be observed releases as opposed to unplanned releases. Table 1 lists the facilities in the 300-FF-1 operable unit that require further remedial investigation under the remedial investigation/feasibility study work plan (DOE 1989a). Table 2 lists the facilities that have been identified by the work plan (DOE 1989a) as currently not requiring further investigation; this list is subject to change.

TABLE 1. Facilities in the 300-FF-1 Operable Unit That Require Further Remedial Investigation (from DOE 1989a)

Retired portions of the Process Sewer and 307 Pipeline $\underline{\operatorname{WIDS}}(\mathrm{a})$ systems (active portions will be investigated in the 300 Area treated effluent study)

South Process Pond (including Retired Filter Backwash Pond) 316-1

North Process Pond (including North Process Pond Scraping 316-2 Disposal Area)

307 Trenches

Process Trenches (b)

316-3

307 Basins $(b)$

$316-5$

Burial Ground No. 4

Burial Ground No. 5

$618-5$

Retired Radjoactive Liquid Waste Sewer Lines

340 Complex(b)

Sanitary Sewer System (b)

Ash Pits (b)

Filter Backwash Ponds $(b)$

(a) From the Waste Information Data System.

(b) Facilities that are active in whole or in part. 
TABLE 2. Facilities in the 300-FF-1 Operable Unit That Do Not Require Further Remedial Investigation (from DOE 1989a)

Radioactive Liquid Waste Sewer Lines (leak detection system in place) 340 Complex Hazardous Waste Staging Area (no documented releases)

332 Hazardous Waste Staging Area (no documented releases)

Some of the facilities noted in Table 1 are partly or wholly active. For example, the Process Trenches (316-5), the 307 Basins, and the 340 Complex are in current use and are being operated as interim-status Resource Conservation and Recovery Act (RCRA) facilities. Compl icating the picture are facilities that have retired portions, such as the Process Sewer system with abandoned lines going to the North and South Process Ponds (316-2 and $316-1)$, as well as past spills and unplanned releases around active units. This report considers only those facilities or parts of facilities that are inactive, retired, or abandoned. 


\subsection{INTERVIEWS WITH KNOWLEDGEABLE PERSONNEL}

Four key people contributed in-depth information to various aspects of this report. Mr. Michael E. Thurman, Westinghouse Hanford Company (Westinghouse Hanford), Defense Waste Management/Solid Waste Management, provided a tour and overview of the 340 Complex. Mr. Roy M. Gale, Pacific Northwest Laboratory (PNL), Engineering and Craft Services, furnished information on the current status of the basic sewer systems in the 300 Area. Mr. Victor $H$ Tarr, Kaiser Engineers Hanford Company, Construction Forces, led an on-site tour of the retired radioactive waste sewer monuments. Mr. Robert B. Hall, PNL, Atmospheric Sciences Department, and formerly Westinghouse Hanford, described many historical aspects of 300 Area operations.

In addition, Mr. Cameron M. Andersen, PNL, described physical controls that prevent the introduction of radioactive and hazardous wastes to the Process Sewer, and Messrs. Lawrence B. Priest, Glenn T. Thornton (both PNL), and Earl E. Gest (Westinghouse Hanford) provided details on photochemicals and some acids released to the Process Sewer. 


\subsection{SOURCE DATA COMPILATION}

The following sections present each waste stream in the context of its origin, transfer, and temporary and/or ultimate disposal.

\subsection{AREA SEMR SYSTEMS}

\subsubsection{Basic Sewer System}

Most buildings in the 300 Area are serviced by one or more of the following sewers: sanitary, process, retention process, and radioactive 7iquid waste (Figure 2).

The Sanitary Sewer carries waste water from lavatories and kitchens, first to septic tanks and then to two Sanitary Leach Trenches located at the northeast corner of the main 300 Area complex between the North and South Process Ponds (316-2 and 316-1); all within the 300-FF-1 operable unit.

The current Process Sewer, connected to 43 buildings, transfers process liquid wastes that include cooling water, steam condensate, process water from the fuels fabrication operations, and liquids from laboratory sink and

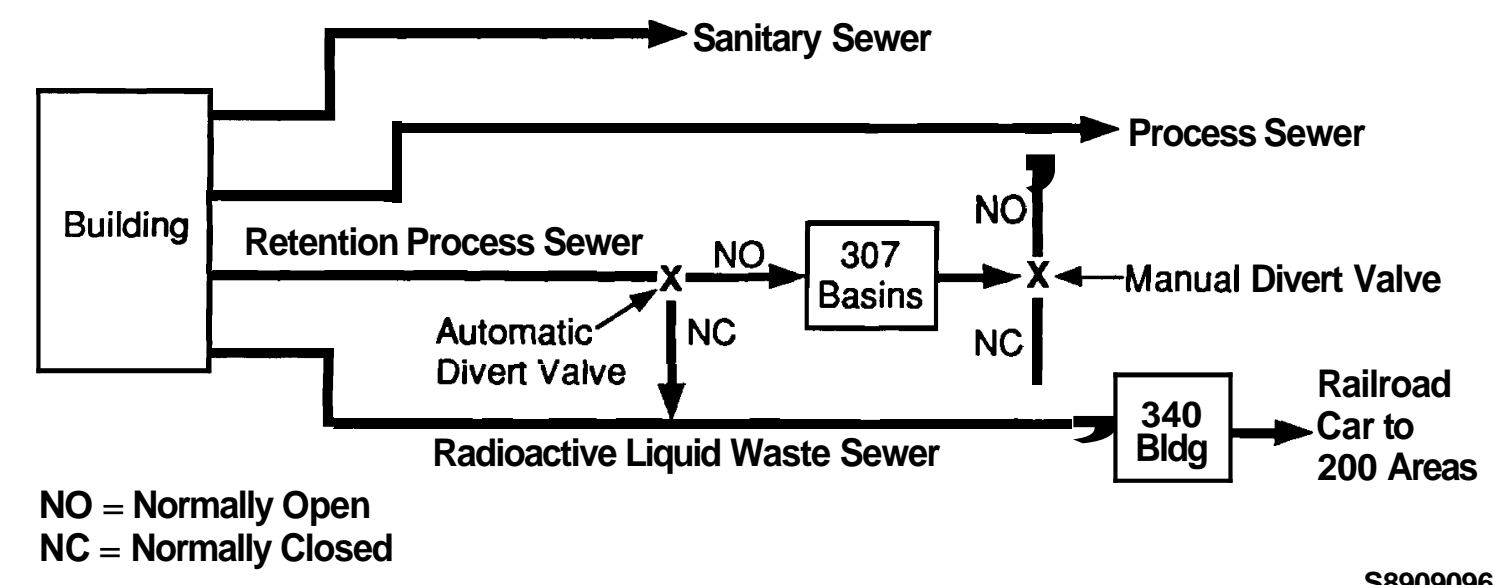

S8909096.1

FIGURE 2. Schematic of the 300 Area Basic Sewer System 
floor drains to the Process Trenches (316-5) in the northwest portion of 300-FF-1. At present, process wastes are supposed to be free of radioactive materials, although originally they contained radioactive contaminants, especially uranium. Prior to construction of 316-5 in 1975, these wastes were carried to 316-1 and 316-2. From 1943 to 1953, the first ten years the Process Sewer and 316-1 were in use, the only discharge of radioactive waste, other than uranium, came from small analytical laboratories in the 3706 Building. During 1952 and 1953, the 325, 326, 327, and 329 Buildings were constructed, and their wastes were added to the radioactive load. In 1953, a separate laboratory waste transfer and disposal system (the original Radioactive Liquid Waste Sewer and the Retention Process/307 system) was installed to serve the new laboratory buildings. This removed much of the radioactive burden to the Process Sewer. Potentially contaminated liquid waste from the Retention Process Sewer was directed to four 50,000-gal concrete basins (307 Basins), where it could be retained and monitored for radioactivity. This part of the 307 system is still in use. If radioactivity was below set limits, waste then went to the 307 Trenches (316-3) (Section 3.2.1.3) ; otherwise it was directed to the 340 Complex. The laboratory system was operated independently of the Process Sewer until 1963, when they were reintegrated after abandonment of 316-3. Retention process waste is now disposed in 316-5; however, the 307 Basins still allow for screening of wastes too high in radioactivity for final disposal in the 300 Area. This radioactive waste is diverted to the 340 Complex (see Figure 2). In addition to radioactive substances, a wide variety of chemicals also entered the Process Sewer in the past.

The Retention Process Sewer now carries potentially radioactive waste from the 324, 325, 326, 327, 329, and 3714 Buildings to either the 307 Basins or the Radioactive Liquid Waste Sewer, depending on whether the waste stream is radioactive. If a level of activity greater than $55,000 \mathrm{pCi} / \mathrm{L}$ is detected by a continuous monitor in or near a building, a diverter valve automatically routes the flow to the Radioactive Liquid Waste Sewer. If the waste stream is at or below this level, it is sent to the 307 Basins, where it is again monitored for radioactivity. If the retained waste is found to be 
radioactive, it is sent manually to the Radioactive Liquid Waste Sewer and the 340 Complex; otherwise it goes to the Process Sewer.

The current Radioactive Liquid Waste Sewer, a double-walled pipe installed in the late 1970 s as an upgrade of the original single-walled system, which was retired and abandoned in 1979, transfers intermediate-level radioactive waste and potentially contaminated process water by gravity flow from a limited number of sink drains in the $324,325,326,327$, and 329 Buildings into underground neutralization tanks in the 340 Complex or stainless steel storage tanks in the 340-B Building. The waste is then transported by railroad tank car to the 200 Areas for disposal.

\subsubsection{Process Sewer Controls}

Administrative controls to prevent the introduction of radioactive and hazardous waste constituents into the Process Sewer are based on DOE orders and applicable federal, state, and local regulations. The DOE orders include 5420.1，5440.1B，5480.1，5480.2，5480.4，5480.5，5484.1, and 5820.2. These orders and RCRA and state regulations have been incorporated by PNL and Westinghouse Hanford into management manuals.

Releases to the Process Sewer and the Retention Process Sewer are limited to dilute aqueous wastes of miscible nonradioactive chemicals, drain and aquaculture overflows, and small amounts of thermal discharges. Radioactive liquid waste exceeding $1 \%$ of DOE Order 5480.1, Chapter XI, Attachment XI-1, Table II, shall not be discharged to the Retention Process Sewer or to the Process Sewer without approval from the PNL Safety Department. If concentrations of radioactive and other hazardous materials in a gaseous or liquid effluent stream exceed the concentration guides, the building manager or another responsible line manager, on being notified, shall promptly begin the necessary actions to reduce the abnormal release to below the concentration guide.

There are physical controls in addition to the administrative controls. All drains from process tanks are locked and tagged. To open them, a researcher must contact the building manager with a letter of approval from PNL Waste Management that documents that the material to be discharged to the Process Sewer is 1) nonhazardous, 2) nonradioactive, and 3) nonregulated. 
It is the researcher's responsibility to provide the solution's composition, if known, or obtain an analysis, if unknown. All floor drains are either plugged or have standpipes to prevent an uncontrolled spill to the Process Sewer. All 1aboratory sinks and hood drains are posted as nonhazardous disposal sites. Steam or water effluents that are used for heating or cooling process tanks are cleaned before and after their use. These are the only liquids discharged directly to the Process Sewer.

\subsection{RETIRED SEMER SYSTEMS}

\subsubsection{Retired Process Sewer System}

The retired portions of the Process Sewer within the 300-FF-1 operable unit consist of inactive portions of the Process Sewer lines, the North and South Process Ponds (316-2 and 316-1), and the 307 Trenches (316-3).

\subsubsection{Retired Process Sewer Lines}

The Process Sewer is reviewed in the 300-FF-1 work plan (DOE 1989a). In brief, the Process Sewer was originally constructed in 1943 to carry process liquid wastes from various buildings in the 300 Area to 316-1. The sewer was extended in 1948 to serve the then new 316-2, modified in 1953 to allow the use of both ponds, and extended again in 1975 to transfer wastes to the Process Trenches (316-5). The sewer is constructed primarily of vitreous clay sewer pipe with acidproof, gasketed bell and spigot joints.

When 316-1 and 316-2 were replaced by 316-5, which lie just west of 316-2, most of the sewer lines were retained and only those portions leading to the ponds were sealed and abandoned. The retired Process Sewer line leading into 316-2 begins at Hanford Coordinates N 56053.37/E 15382.08, where it branches, presumably at a manhole, from the line that currently feeds $316-5$ (see Figure 1). The as-built drawing (M-3904, Sheet 1, April 28, 1989) does not indicate how it is isolated. The line ends in the southeast sediment storage basin.

The Process Sewer pipe that emptied into the northwest corner of 316-1 runs from a diversion box at $N 55263 / E 15521.78$ to a wingwall in the northwest corner of 316-1. This line appears on the as-built drawing (M-3904, 
Sheet 2, October 1980) as not having been abandoned; thus, there is no indication that the line is plugged.

The abandoned pipe that fed the southwest corner of 316-1 runs from a manhole just outside the 300-FF-1 operable unit at N 54628.23/E 15091.0 to the 316-1 inlet at $\mathbf{N}$ 54730.0/E 15575.0. The 18-in.-diameter pipe is sealed at the manhole, but has a 6-in. plugged opening.

A system of abandoned 8-in. 1ines (composition unknown) extends from the 307 Basins to the two retired 316-3 trenches as shown in Figure 1 . On the as-built drawing (M-3904, Sheet 3, September 1, 1971), 1ines leading from the center of each retention basin join at N 54339.72/E 15403.5 to form a single pipe that extends approximately $15 \mathrm{ft}$ south to $\mathrm{N} \mathrm{54323.30.} \mathrm{There,} \mathrm{it} \mathrm{angles}$ southeast approximately 110 ft to N 54250/E 15475, where it spl its to feed each of the trenches, one at N 54250 and the other $50 \mathrm{ft}$ to the south at $N$ 54200. In addition to the 8-in. line shown on the as-built drawing, there is a 4-in. line that runs from the 340 Building, between the 307 Basins, to join the 8-in. line near N 54339.72/E 15403.5. The composition of this pipe also is not known at this time.

\subsubsection{Retired North and South Process Ponds}

The North and South Process Ponds (316-2 and 316-1) are two inactive, unl ined surface impoundments in the 300-FF-1 operable unit approximately $300 \mathrm{ft}$ west of the Columbia River (see Figure 1). They were built in 1943 and 1948 (316-1 and 316-2, respectively), and used for disposal of all radioactively and chemically contaminated process waste waters from the 300 Area. After construction of the 307 Basins and 316-3, some radioactive waste was transported to the 200 Areas for disposal. 316-2 was built in response to a 316-1 dike failure in 1948 that released contaminated liquid into the Columbia River. 316-1 was later repaired and the two ponds were operated until 1975, when they were replaced by the Process Trenches (316-5). The east infiltration basin of 316-1, however, remained active for the disposal of water treatment filter backwash until late 1986. Both ponds (316-1 and 316-2) are now dry, and portions of the surfaces have been covered for stabilization. 
The ponds were operated as a series of basins. The structure of 316-1 changed several times over the years, but its final configuration consisted of three small settling basins on its west side and two larger infiltration basins to the east, each separated by 15 -ft-high dikes. The entire series of basins covered eight acres. The dike separating the infiltration ponds is $100 \mathrm{ft}$ wide; other dikes are 16 to $30 \mathrm{ft}$ wide; some have been removed as indicated below. The inlet was located on the southwest corner of 316-1 until 1953, when it was moved to the northwest corner, and the Process Sewer was modified to allow either simultaneous or alternating use of both 316-1 and 316-2. Along with radioactive (primarily uranium) waste, 316-1 received small amounts of organic waste from the 303 area floor drains and 5 to $10 \mathrm{gal}$ per week of bottled organic solutions. These wastes entered the pond via a stainless steel pipe running along the north dike.

316-2 received waste mainly from the Process Sewer, which carried cooling water and low-level radioactive liquid waste from fuel fabrication operations in the 3706 Building with other "incidental" waste from the 3706 and 321 Buildings and wastes from the 313 Building. Prior to 1957, 316-2 received trucked-in liquid wastes. Liquid that entered the pond flowed from basin to basin through flumes located at the tops of the dikes. Suspended solids settled in each of the basins, and since there was no outlet, the liquid either evaporated or entered the soil of the infiltration basins.

After the 1948 dike failure, 316-1 was periodically dredged to improve infiltration. Stenner et al. (1988) reported that in 1949 and 1953 316-1 and 316-2 were dredged and the sludge was removed and buried on the edge of the ponds and dikes. ICF Northwest (1987a) gives the years 1948 and 1952, and adds that the dredging was by dragline. 316-1 was again dredged by earthmover in 1957, 1965, and 1969 (ICF Northwest 1987a). Lack of infiltration was a continuous problem caused by the disposal of sodium aluminate, which was trucked in until 1956, then later carried through the sewer. The sodium aluminate would precipitate solids and restrict infiltration. In 1965, a plan was approved to dispose of $10,000 \mathrm{yd}^{3}$ of dredged pond sediments in 316-3, which was no longer used. The estimated chemical inventory of these sediments included 20,000 $\mathrm{kg}$ of copper, $10,000 \mathrm{~kg}$ of uranium, $3000 \mathrm{~kg}$ 
of nickel, $1000 \mathrm{~kg}$ of chromium VI, and $600 \mathrm{~kg}$ of 1ead, plus other metals and anions (ICF Northwest 1987a). Dredging was discontinued after 1969 when the production of aluminum-clad fuel ceased, ending the disposal of sodium aluminate. After 1975, when both ponds were deactivated, the east infiltration basin was used as a filter backwash pond until 1987. Filter backwash is considered nonhazardous. Some of the dikes separating the settling ponds were excavated and used as cover for the pond sediments. The amount of material removed has not been determined, but the bases of these dikes are still visible in recent aerial photographs.

The North Process Pond (316-2) originally consisted of a single large infiltration basin, but was later subdivided into three small settling basins and one large infiltration basin separated by 15 -ft-high and 12 -ft-wide dikes at the top. The entire 10-acre pond was surrounded by a 15 -ft-wide and 10-ft-high dike. As with 316-1, flumes on top of the dikes allowed the flow of liquid between basins. In approximately 1961 or 1962, the three settling basins were replaced with three new basins just to the east, within the $316-2$ boundary, and the original basins were retained for sediment disposal. The inlet for 316-2 was at the southwest corner, but there was no outlet. Water would infiltrate or evaporate from the infiltration basin after sediment was caught in the settling basins.

From 1949 to 1974, the site received low-level radioactive wastes and cooling water from the 3706 Building, aqueous wastes containing unirradiated uranium from the 313 Building, and water from the floor drains of the 303 Building. The wastes flowed through the 307 Basins en route to 316-2 until the site was retired in 1974. 316-2 was reportedly dredged by dragline in 1952, 1954, and 1955 and by earthmover in 1960, 1964, and 1969 to increase the infiltration rate (ICF Northwest 1987a). Some of the subdividing dikes were bulldozed to cover the pond bottom and prevent wind dispersal of contaminated sediments.

The 316-2 scraping disposal area extended approximately $200 \mathrm{ft}$ south of the pond and was used for disposal of uranium-contaminated soil from the bottom of the pond and from beneath the 321 Building during excavation for 
hydraulic core mockup. The site has since been backfilled with coal ash (Stenner et al. 1988) and covered with fill.

Total uranium discharged to $316-1$ and $316-2$ was 40,300 I b by October 1956 (Heid 1956) and 130,000 1b through 1970. Total copper discharged through 1970 was 160,000 to 240,000 1b (DOE 1989a).

In 1970, 316-2 sediments were sampled to a depth of $4 \mathrm{ft}$ and showed a fairly even distribution with depth of copper, uranium, and zirconium (Appendix, Letter 1). In 1974, radiation survey of the floor of 316-1 indicated ${ }^{60}$ Co was a significant gamma emitter, and chemical analyses detected fluoride, beryllium, and various heavy metals, including uranium (Appendix, Letter 2). A 1975 study (Appendix, Letter 3) confirmed data for lead, copper, and uranium collected in 1974, but also noted similar values for sediments in the east and west walls of the east basin. These walls consist in part of dredgings removed from the pond bottom. More recent data were adequately reviewed (DOE 1989a), including those covered by Stenner et a1. (1988) and Dennison et a1. (1989).

Polychlorinated biphenyls (PCBs), particularly Arochlor 1248, were found in sediments of both 316-1 and 316-2 (Dennison et al. 1989). Disposal of PCBs to these facilities was not documented.

\subsubsection{Retired 307 Trenches}

The 307 Trenches (316-3) were operated from 1953 to 1963 to dispose of potentially contaminated laboratory retention wastes received by the 300 Area laboratory waste system. There were two parallel trenches (see Figure 1) $600 \mathrm{ft}$ long, $10 \mathrm{ft}$ wide, and $20 \mathrm{ft}$ deep (Hanford Coordinates N 54265/E 16000, N 54185/E 16000, N 54185/E 15475, N 54265/E 15475). The buildings serviced by this system were 325 (radiochemistry), 326 (pile techno1ogy), 327 (radiometallurgy), 329 (biophysics), and 308 (fuels development, which was added in 1960). Wastes were carried via the Retention Process Sewer to one of the four 50,000-gal 307 Basins and held for analysis. If the analysis was below the discharge limits, the wastes were discharged to 316-3; otherwise, they were transferred to the 340 Complex for crib disposal in the 200 Areas. Difficulties in sampling allowed liquid waste that had not been analyzed to 
be released to $316-3$, perhaps as much as $40 \%$ (Haney 1960), possibly resulting in the discharge of radioactive waste in concentrations above DOE guidelines.

In 1963, 316-3 was taken out of service and later backfilled with $10,000 \mathrm{yd}^{3}$ of contaminated sediments mostly excavated from 316-1, with some coal ash and other sediments as well. Sediments in 316-1 were contaminated with uranium, copper, and other heavy metals (ICF Northwest 1987b, Dennison et al. 1989). The results of five analyses of visibly contaminated soils from a recent excavation are given in DOE (1989a).

The draft RI work plan for 316-3 (ICF Northwest 1987b) indicates that not enough groundwater monitoring data are avail able to judge the contribution of uranium from 316-3 to the underlying groundwater, and that not enough wells are close enough to the site for accurate characterization. The plan states that several wells in the vicinity of $316-3$ are no longer in use, which, however, is not the case. Dennison et a1. (1989), using groundwater data from 1986, show a composite plume of uranium greater than $30 \mathrm{pCi} / \mathrm{L}$ originating from 316-5 on the north end of the 300 Area and in the area of 316-3 and leading toward the Columbia River. A review of groundwater data from 1980 to the present adds supporting evidence of elevated uranium in the groundwater near 316-3 in addition to the larger, northern source from 316-5.

If $316-3$ is the southern source of the composite uranium plume, the mechanism of the contamination is not clear. Since $316-3$ is no longer in use and there is no liquid discharge to it, the only other mode of uranium migration to groundwater is leaching of contaminants associated with disposed 316-1 sediments. The potential for migration along this pathway depends on the leachability of uranium from the sediments and the infiltration of water for leaching. The contaminants are not expected to be very soluble, but the coarse soils and shallow-rooted plants that characterize the 300 Area allow rapid water infiltration and groundwater recharge (Gee 1987).

\subsection{RETIRED RADIOACTIVE WASTE SEWER LINE}

In approximately 1974, the decision was made to upgrade the Radioactive Waste Sewer from a single-walled stainless steel pipe to a double-walled pipe 
to provide a greater margin of safety against leakage into the environment. Project V-659 was the construction project for replacement of these sewer lines. Project V-680 made modifications to 300 Area laboratory buildings for replacement of the sewer lines. All reports and documents relevant to these projects are contained in Central Files, 3706 Building, on microfilm cassettes entitled Project V-659 and Project V-680.

The original Radioactive Liquid Waste Sewer was approximately $3600 \mathrm{ft}$ of 2-, 3-, 4-, and 6-in.-diameter single-wall stainless steel pipe that served the 324, 325, 325A, 326, 327, and 329 Buildings (Figure 3). The 308 Building was tied into the sewer system at one time, but was capped off sometime before the line's retirement. The line, buried up to $18 \mathrm{ft}$ deep, was constructed around 1953 and was retired from service in 1979. A separate 3-in. carbon steel transfer line installed in 1960 connected the 309/Plutonium Recycle Test Reactor to the 340 Building to transfer reactor operational liquid waste, such as resin backwash and deionizing solutions. There were no isolation valves, radiation monitors, or other leak-detection capabilities. There were no facilities built into the system that would permit meaningful testing. The lines handled approximately $25,000 \mathrm{gal} / \mathrm{mo}$ (the volume varied considerably) of beta-gamma radioactive waste, with an upper radiation leve 1 of $20 \mathrm{rem} / \mathrm{h}$.

The old Radioactive Liquid Waste Sewer was replaced by the present sewer, a stainless steel inner pipe surrounded by a fiberglass-reinforced epoxy encasement. The present sewer was built to be independent of the old sewer and follows a different route, although it services the same facilities.

The original sewer was retired by cutting the pipe where it entered a building and sealing the severed end with a welded stainless steel cap. During its construction, cleanouts had been installed at most of the places where the line changed direction. At retirement, the cleanouts that were located (and it is likely that not all were found) were sealed with a gasketed flange and marked with a bronze monument. Each monument has a sketch of the old sewer system, a reference drawing number, a cleanout letter designation ( $A, B, C$, etc.), the words "ABANDONED RLW," a radiation symbol, and 


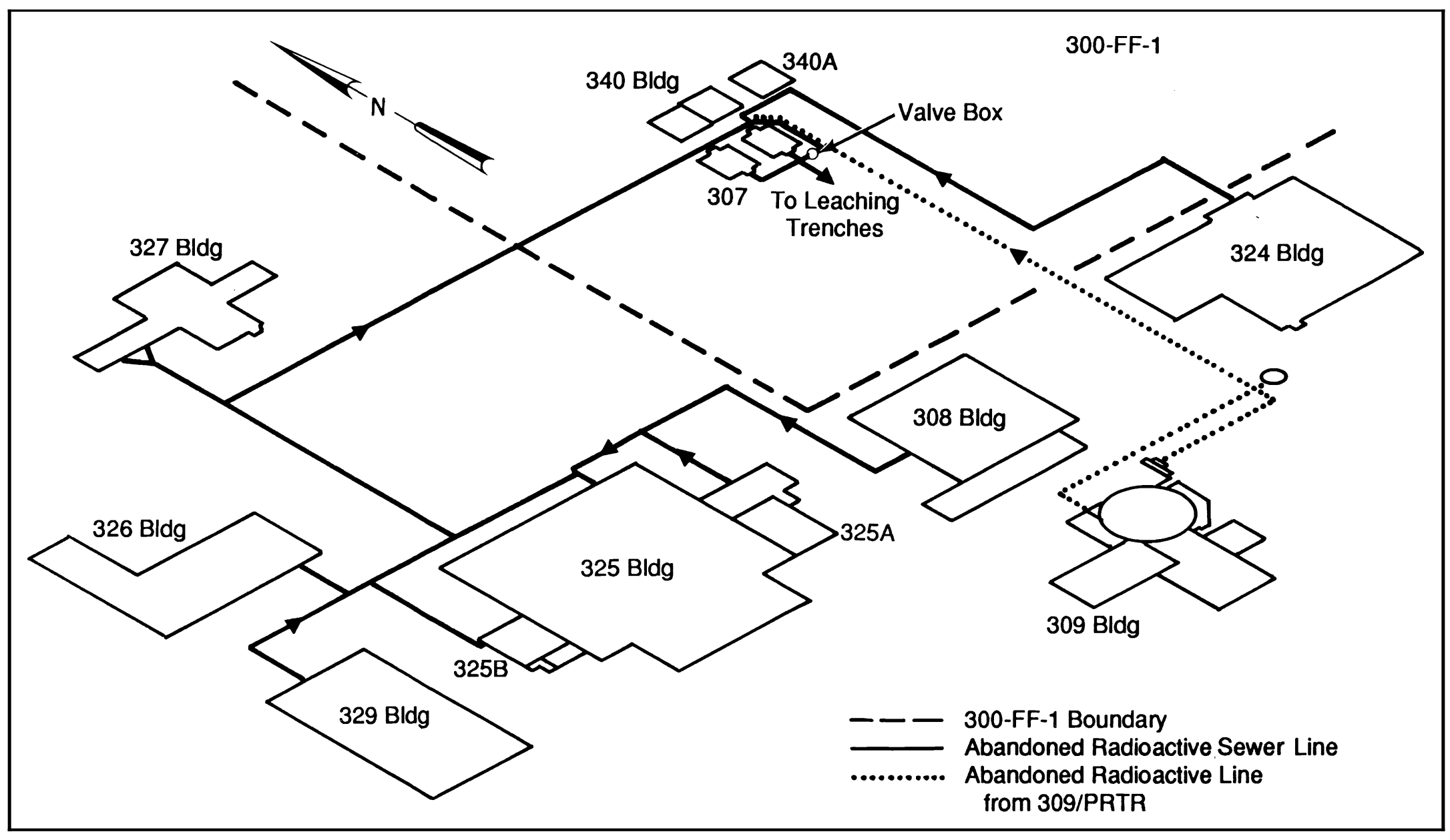

FIGURE 3

ioacti quid Waste Sewer 
the Hanford coordinates of the monument location (Figure 4). Eleven monuments were proposed (A through $\mathrm{K}$ ) at the coordinates 1isted in Table 3.

The 309/Plutoni um Recycle Test Reactor radioactive waste transfer line was decommissioned in 1983 or 1984 . The end of this line at the reactor was cut and capped, but the line did not have, a monument. According to Mr. Victor Tarr, the pipe retains residual radioactive contamination. Messrs. Robert Hall and Victor Tarr, who had both participated in the old Radioactive Liquid Waste Sewer retirement, affirmed that prior to isolating the system, radioactive waste was flushed from connecting pipes that led from the buildings into the main part of the underground sewer. The floor drains in the buildings were then sealed, and the sewer lines outside the buildings downstream of the drain connections were cut and capped. This means that the main part of the old sewer still contains radioactive material.

It is the opinion of all who have investigated the old sewer abandonment that pressurizing the line with a tracer gas to detect leaks may force radioactive material from the pipe into the surrounding soil. According to Mr. Robert Hall, cathodic protection for the stainless steel pipe was removed at the time of abandonment, so sections of the pipe may have corroded and weakened. Also, gaskets that sealed the flanges at the cleanouts may have deteriorated with time and would have to be located and replaced before the line could be pressurized. Alternatives to a pressurized tracer gas survey are presented in Section 4.4.

\subsection{UNPLANNED RELEASES AND SPILLS}

\subsubsection{UPR-300-1}

On December 9, 1969, a leak was discovered in the transfer line between the 307 Basins and the 340 Complex waste tanks (Denham Undated). A short, underground, 3-in.-diameter, carbon steel transition pipe that joined the cast iron transfer line from the 307 Basins to the stainless steel Radioactive Liquid Waste Sewer 1 ine had corroded so that the bottom portion of the pipe was missing. Retention waste (also called crib waste) had backed up and filled that portion of the line, causing the corrosion. It was estimated 


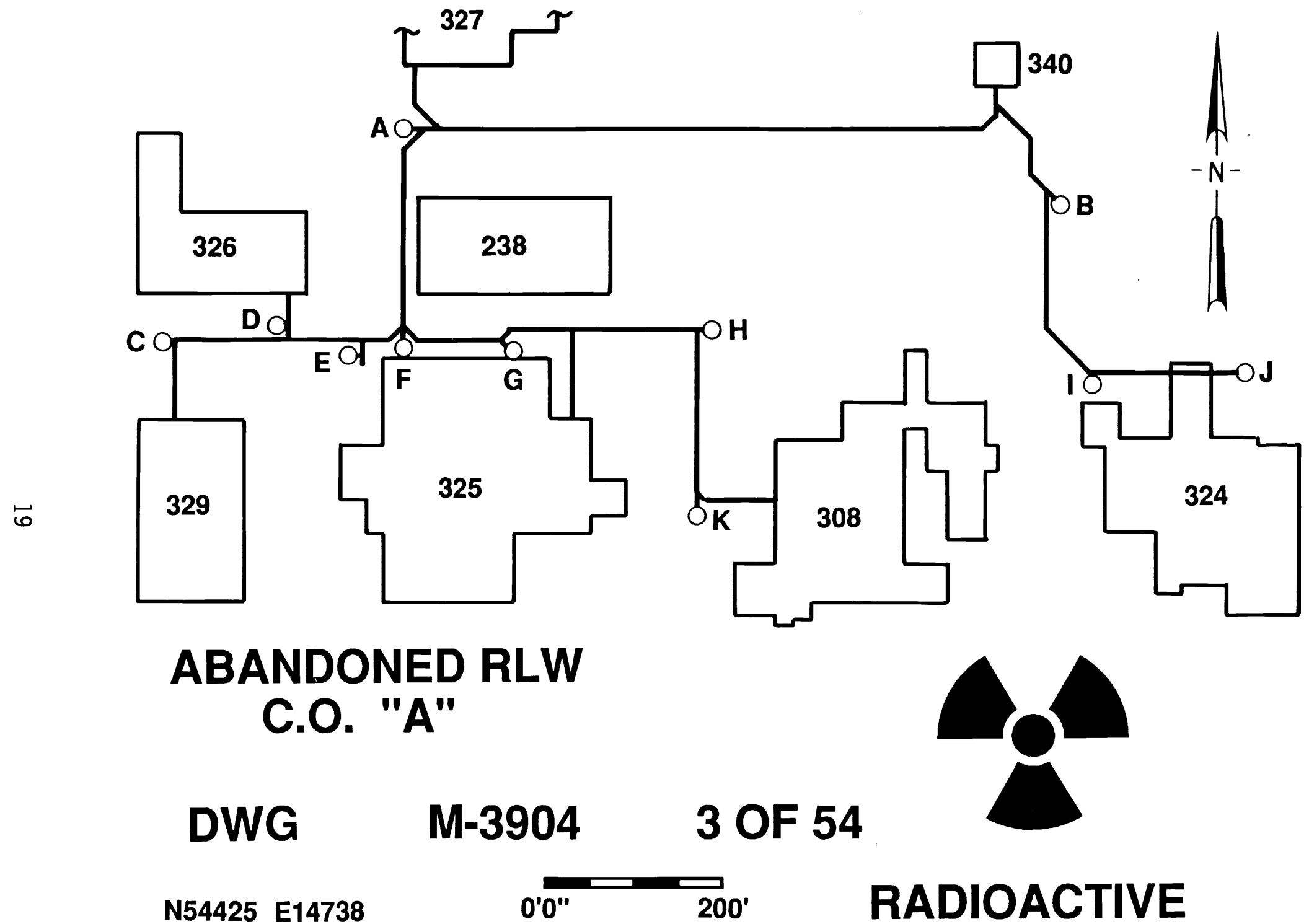

FIGURE 4. The Bronze Monument Marking a Cleanout of the Abandoned Radioactive Liquid Waste Sewe 
TABLE 3. Approximate Coordinates of Cleanouts A through $K$ of Retired Radioactive Liquid Waste Sewer(a)

Cleanout

Desianation

A

B

D

$\mathrm{E}$

G

$\mathrm{H}$
$\mathrm{J}$
$\mathrm{K}$
Hanford Coordinates

N $54425 \quad$ E 14738

N 54344 E 15462

N 54143 E 14476

N 54155 E 14590

N 54138 E 14668

N 54152 E 14731

N 54132 E 14853

N 54149 E 15075

N 54138 E 15514

N 54140 E 15700

N 53969 E 15070

(a) It has been indicated that not all the cleanouts may have been found.

that the pipe had been leaking for at least one year. The radioactive waste leaked into the soil approximately $5 \mathrm{ft}$ below grade, contaminating an area $12 \mathrm{ft}$ in diameter and $25 \mathrm{ft}$ deep. Table 4 gives an estimated inventory of radionuclides and volumes of contaminated soil based on radiochemical separation and direct gamma analysis of core samples and calculations of the mass of soil affected. Groundwater from a test well at the site was not radioactive. The top $2 \mathrm{ft}$ of contaminated soil were placed in drums and removed to burial grounds in the 200 Areas. Further removal of contaminated soil was considered a threat to adjacent structures.

Twenty years have passed since the spill and a good portion of these radionuclides have decayed away, although ${ }^{90} \mathrm{Sr},{ }^{137} \mathrm{Cs}$, and ${ }^{241_{A m}}$ are still abundant. The ${ }^{147} \mathrm{Pm}$ has passed through more than 7.5 half lives. The Hazard Ranking System (HRS) Migration Score for this unplanned release is 26.604 (Stenner et al. 1988).

\section{$3.4 .2 \quad \underline{U P R}-300-2$}

Stenner et al. (1988) described this 1954 unplanned release as approximately $10 \mathrm{mC}$ i of ${ }^{137} \mathrm{Cs} 10$ to $20 \mathrm{ft}$ north, east, and south of the 340 Building. There was no mention of any cleanup action; however, contamination was 
TABLE 4. Inventory of Radionuclides and Volume of Contaminated Soil Beneath the Corroded 307 Basin Transfer Lines

\begin{tabular}{|c|c|c|}
\hline $\begin{array}{l}\text { Radio- } \\
\text { nuclide }\end{array}$ & $\begin{array}{l}\text { Total Activity } \\
\text { (Ci) as of June } 1,1970\end{array}$ & $\begin{array}{r}\text { Contamin } \\
\text { Soil Volum }\end{array}$ \\
\hline $\begin{array}{l}147 \mathrm{Pm} \\
106 \mathrm{Ru} \\
144 \mathrm{Ce} \\
90 \mathrm{sr} \\
137 \mathrm{Cs} \\
241 \mathrm{Am} \\
134 \mathrm{Cs} \\
95 \mathrm{Zr} \\
103 \mathrm{Ru} \\
141 \mathrm{Ce} \\
95 \mathrm{Nb}\end{array}$ & $\begin{array}{c}800 \\
20 \\
20 \\
10 \\
10 \\
0.7 \\
0.4 \\
0.2 \\
0.04 \\
0.03 \\
0.02\end{array}$ & $\begin{array}{l}70 \\
40 \\
70 \\
70 \\
40 \\
20 \\
30 \\
40 \\
40 \\
70 \\
10\end{array}$ \\
\hline
\end{tabular}

not present in 1978 during renovation excavation. This unpl anned release has an HRS Migration Score of 18.268.

\subsubsection{UPR-300-11}

In October 1977, during the V-659 Project, radioactive liquid waste was found to have leaked from flanges connecting a tee to the sewer line that enters the 340 Building. The leak had gone undetected until the line was uncovered. Less than $10 \mathrm{Ci}$ of fission products were found in soil samples, and no alpha-emitting radionuclides were detected. Approximately $22 \mathrm{ft}^{3}$ of soil were contaminated in the form of a column approximately $1 \mathrm{ft}$ in diameter that extended to approximately $17 \mathrm{ft}$ below the Radioactive Liquid Waste Sewer line. At that depth, contamination spread laterally in an interface between the undisturbed soil and the backfill. Evidence of contamination from a separate event also was found, somewhat blurring contamination boundaries (Hall 1978, HEDL 1977). Physical conditions prevented characterization of the second contaminated soil column. Approximately $90 \%$ of the contamination was removed by excavating the soil to approximately $8 \mathrm{ft}$ below grade and transporting it to the 200 Areas for burial. Approximately $1 \mathrm{Ci}$ was left in place. The HRS Migration Score is 17.427 (Stenner et al. 1988).

\subsubsection{Phosphoric Acid Spill}

Several 55-gal plastic drums of phosphoric electrolyte, .purchased around 1977, were stored outdoors where weather deteriorated the labels. At some 
point, one drum of the phosphoric-chromic acid mixture was mistakenly identified as nitric acid. In mid-1985, this drum (containing approximately 30 gal of phosphoric electrolyte) was shipped to the 340 Building with the presumption that it was nitric acid that could be used in $\mathrm{pH}$ adjustment operations. At the 340 Complex, the drum was again stored outdoors. It developed a leak, discovered on June 3, 1986, that discharged the entire contents of high-chromium solution to the soil (PNL 1986). The contaminated soil was allegedly excavated, placed in drums, and removed from the site, but this could not be confirmed.

\subsubsection{Other Spills and Releases Near the 340 Complex}

Several past spills and leaks around the 340 Complex contributed significant amounts of radioactivity to the soil. Contamination that extends several feet down next to the 340 Building's south wall suggests that the sump (tanker load out) overflowed during the tanker-truck era, before rail transport of waste. Strontium-90 was identified in the soil. Short-1 ived radionuclides are gone, and the ground surface has been stabilized with clean rock and soil.

In the same vicinity, a tanker-truck valve-maintenance drain was exposed. Minor leakage occurred around the drain pipe. This area also is covered and stabilized, but contamination is known to extend several feet into the soil.

\subsubsection{UPR-600-15}

During September 1979, 20 depleted urani um fuel el ements $(0.15 \% 235 \mathrm{U})$ were found improperly discarded at Burial Ground No. 4 (618-4). The fuel elements and contaminated soil were removed and buried by November 1979 in the mixed fission product trench in 218-W-3A. This unplanned release has an HRS Migration Score of 26.123 (Stenner et al. 1988).

\subsection{OTHER FACILITIES}

\subsubsection{Burial Ground No. 4}

Burial Ground No. 4 (618-4) occupied a 570- x 220- x 15-ft-deep area in the northwest corner of the $300-\mathrm{FF}-1$ operable unit (the southwest corner is 
at $N$ 57832/E 14546). This burial ground was used from 1955 to 1961 to dispose of miscellaneous uranium-contaminated materials. No inventory is available.

\subsubsection{Burial Ground No. 5}

Burial Ground No. 5 (618-5) was a 300- x 18- x 15-ft-deep trench at the north end of 300-FF-1 just east of the Process Trenches (316-5) (the southwest corner is at N 57245/E 15429). This burial ground was used from 1945 to 1962 as a burning pit for uranium-contaminated and nonradioactive trash collected from the 300 Area. The burial ground was covered with $4 \mathrm{ft}$ of clean soil.

\subsubsection{Process Trenches}

The two Process Trenches (316-5) are $1500 \mathrm{ft}$ long, $12 \mathrm{ft}$ deep, and are separated by an earthen berm. Constructed in 1975, 316-5 received process wastes from the 300 Area facilities via the Process Sewer lines. The trenches are located in the northeast part of the 300-FF-1 operable unit near the Columbia River. The trenches received hazardous constituents in low concentrations unti1 February 1, 1985, when administrative controls were instituted to prevent the disposal of dangerous wastes. Estimated chemicals discharged to the trenches prior to February 1, 1985, are summarized in Table 5. The trenches continue to receive approximately 1.5 to $2.0 \times 10^{6} \mathrm{gal}$ of waste water per day, consisting primarily of cooling water with small quantities of nonhazardous maintenance and process wastes.

There are two general categories of photochemicals generated in the 300 Area, some of which go to 316-5: 1) regulated chemicals in the fixer and hardener solutions and 2) nonregulated chemicals composed of stop bath and activator chemicals. The nonregulated chemicals are transported to the 326 Building, where they are discharged to the Process Sewer.

The stop bath consists of acetic acid plus water; the activator solution consists of potassium hydroxide and potassium sulfite. The fixer and the hardener solutions may be of different compositions, depending on the brand of the product. Typically, these chemicals include acetic acid, gluconic acid, aluminum sulfate, ammonium thiosulfate, sodium thiosulfate, ammonium 
TABLE 5. Estimates of Chemicals Discharged to the Process Trenches (adapted from Schall a et a1. 1988a)

Discharges Prior to Februarv 1985

\begin{tabular}{|c|c|}
\hline in aram amounts & in kilogram amounts \\
\hline $\begin{array}{l}\text { Ammonium bifluoride } \\
\text { Antimony } \\
\text { Arsenic } \\
\text { Barium } \\
\text { Cadmium } \\
\text { Dioxane } \\
\text { Dinxin (b) } \\
\text { Hydrocyanic acid } \\
\text { Pyridine } \\
\text { Seleni um compounds } \\
\text { Thiourea } \\
\text { Mi scell aneous lab- } \\
\text { oratory chemicals }\end{array}$ & $\begin{array}{l}\text { Benzene } \\
\text { Carbon tetrachloride } \\
\text { Chlorinated benzenes } \\
\text { Chromi um } \\
\text { Degreasing sol vents } \\
\text { Formaldehyde } \\
\text { Formic acid } \\
\text { Hexachl orophene } \\
\text { Kerosene } \\
\text { Lead } \\
\text { Mercury } \\
\text { Methyl ethyl ketone } \\
\text { Naphthal ene } \\
\text { Nickel } \\
\text { Perchlorethylene } \\
\text { Phenol } \\
\text { Si lver } \\
\text { Sulfuric acid } \\
\text { Toluene } \\
\text { Tributyl phosphate } \\
1,1,1-T r i c h l o r o e t h a n e \\
\text { Trichl oroethyl ene } \\
\text { Xyl ene }\end{array}$ \\
\hline
\end{tabular}

\section{Discharges Between}

Februarv 1985 and September 1986

$\begin{array}{lr}\text { Copper } & 30 \mathrm{~kg} / \mathrm{mo}(\mathrm{a}) \\ \text { Detergents } & \geq 30 \mathrm{~kg} / \mathrm{mo}(\mathrm{a}) \\ \text { Ethylene glycol } & \geq 200 \mathrm{~L} / \mathrm{mp} \\ \text { Heating oil } & 300 \mathrm{~L}(\mathrm{c}) \\ \mathrm{HCl} & 100 \mathrm{~kg} / \mathrm{mo}(\mathrm{a}) \\ \text { Nitrates } & 22000 \mathrm{~kg} / \mathrm{mo} \\ \text { Nitric acid } & 2300 \mathrm{~L} / \mathrm{mo} \\ \text { NaOH } & 2300 \mathrm{~L} / \mathrm{mo} \\ \text { Paint solvents } & >100 \mathrm{~L} / \mathrm{mo} \\ \text { Photochemicals } & 2700 \mathrm{~L} / \mathrm{mo}(\mathrm{a}) \\ \text { NaCl } & 75 \mathrm{ton} / \mathrm{yr} \\ \text { Urani um } & 20 \mathrm{~kg} / \mathrm{mo}(\mathrm{a})\end{array}$

(a) Chemicals still being discharged.

(b) Included because of the potential for dioxin to exist as a trace impurity in chlorinated benzenes.

acetate, ammonium sulfite, silver, and cadmium. These materials go to the Process Sewer from PNL Photography in the 3705 Building.

The silver concentrations in used photochemicals vary dramatically, so samples are sent out for analysis. Solutions containing less than 500 ppm silver go to the Process Sewer. If the content is greater than $500 \mathrm{ppm}$, the photochemicals are processed to recover the silver. After the silver has been recovered, the remaining liquid is discharged to the Process Sewer.

At the same time a sample is analyzed for silver, it is also analyzed for cadmium. If the cadmium content is greater than $1 \mathrm{ppm}$, the solution is put into containers and transported off the Hanford Site for disposal. 
In addition to photographic chemicals, the Metallographic Laboratory in the 326 Building uses oxalic acid, nitric acid, hydrochloric acid, sulfuric acid, and small amounts of hydrofluoric acid. These acids are diluted, neutralized, and discharged to the Process Sewer.

Twenty-two unplanned releases occurred between the initial operation and 1981 of 316-5. They are individually summarized in Stenner et al. (1988, Vol. 3) and are included as part of the total discharge in Table 5. Since then, there have been two unplanned releases of perchloroethylene to 316-5: 1) on November 4, 1982 (approximately $120 \mathrm{gal}$ ) and 2) on July 6, 1984 (approximately $20 \mathrm{gal}$ ). These are not included in Table 5.

A groundwater monitoring program was begun in June 1985 for 316-5 under compliance orders from the State of Washington Department of Ecology (Ecology). Subsequently, groundwater monitoring has continued, following requirements set forth in RCRA and in Washington Administrative Code 173-303-400. More information concerning 316-5 is contained in schalla et a1. (1988a, 1988b) and in quarterly and annual RCRA progress reports submitted to Ecology and EPA.

By December 1991, 316-5 wi 11 be closed under the Tri-Party Agreement (1989) between the EPA, DOE, and Ecology, when a treatment plant designed specifically to handle process wastes wi 11 be completed. 


\subsection{CONCLUSIONS AND RECOMMENDATIONS}

Within the 300-FF-1 operable unit, both radioactive wastes and toxic chemicals have been discharged to the ground through four engineered facilities: the South and North Process Ponds (316-1 and 316-2), the Process Trenches (316-5), and the 307 Trenches (316-3). 316-1, 316-2, and 316-5 have the highest HRS Migration Score (79.28; Stenner et al. 1988) of any Hanford facility.

\subsection{IDENTIFICATION OF THE SOURCE OF THE URANIUM PLUME IN GROUNDWATER BENEATH THE 300-FF-1 OPERABLE UNIT}

Dennison et al. (1989) and DOE (1989b) identified a groundwater plume beneath the 300 Area that contained measurable concentrations of uranium $(>10 \mathrm{pCi} / \mathrm{L})$. As this appears to be one of the major environmental impacts of fuel fabrication operations, its source should be determined, if possible. The most obvious potential source for the uranium, based on the operating history of the facilities, would be the abandoned $316-1$ or $316-2$ or the currently active 316-5. As expected, a peak in groundwater uranium concentrations occurs $(>30 \mathrm{pCi} / \mathrm{L}$ ) below the general area of these facilities. However, another peak in groundwater uranium (also $>30 \mathrm{pCi} / \mathrm{L}$ ) appears to originate near 316-3. As discussed in Section 3.2.1.3, these trenches were backfilled with contaminated sediments dredged from 316-1. Therefore, we propose that additional characterization of 316-3 be undertaken. This characterization should include areal extent and depth, distribution of the uranium, and presence of any water in the trenches. In addition, the isotopic composition of the uranium should be determined in all of the possible sources of uranium $(316-1,316-2,316-3,316-5)$. Because several different grades of enriched uranium, as well as natural and depleted uranium, have been processed at various times and locations in the 300 Area, the isotopic signature of the contamination in the groundwater may help to reveal its source.

Other possible sources of the uranium plume are leaks from the abandoned or current Radioactive Liquid Waste Sewer leading from the 324 Building, or 
possibly a contaminated Process Sewer line. These lines should be investigated by the techniques discussed below for surveying the abandoned Radioactive Liquid Waste Sewer. Groundwater investigations will be conducted during the 300-FF-5 operable unit remedial investigation/feasibility study (DOE 1989b).

\subsection{SEDIMENT ANALYSES}

Further remedial investigations of 316-1 and 316-2 should continue with its primary focus on near-surface and dike sediment sampling to better define the horizontal extent of contamination. Sediment analyses should include uranium, other radionuclides (such as ${ }^{99} \mathrm{Tc}$ and ${ }^{232} \mathrm{Th}$ ), and PCBs.

\subsection{PHOSPHORIC ACID SPILL}

Numerous documented unplanned releases have occurred in the $300-F F-1$ operable unit, some of which have been remediated. They have had, in aggregate, a very small impact on the environment compared to those documented from the engineered facilities. As conveyed in Section 3.4.4, the phosphoric acid/chromic acid spill in 1986 involved only $30 \mathrm{gal}$ of waste. The spill was remediated shortly after it occurred; therefore, further investigation of this spill will be limited to perhaps a surface grab sample at the location.

\subsection{ALTERNATIVES TO THE TRACER GAS SURVEY OF THE RETIRED RADIOACTIVE LIOUID WASTE SEMER}

An unknown impact has occurred from possible undocumented leaks in the various sewer systems in the 300-FF-1 operable unit. Revision 1 of the work plan for this unit suggested the use of a tracer gas to detect any leaks in the abandoned Radioactive Liquid Waste Sewer. This procedure is not recommended for two reasons. The first is the fear that residual radioactivity, which is known to be present in the abandoned sewer, will be forced into the surrounding soil. Because there is no way to isolate the $300-F F-1$ portion of the sewer line, this leakage could occur anywhere along the length of the line. The second is the high probability of false negatives caused by the 
deep (up to $18 \mathrm{ft}$ ) burial of the pipes. Because of the deep burial, it is very likely that leaking tracer gas will not reach any of the wells drilled to sample it. The large number of wells required to overcome this problem would be prohibitively expensive.

Two potential "in-pipe" techniques would appear to lend themselves to investigation of this sewer. One is an electromagnetic induction technique (known as the eddy-current inspection). In this technique, the excitation source and the receiver are both enclosed in a remote probe that is fed into the pipe. Having both units in the pipe greatly reduces interference from other nearby pipes and cables and greatly simplifies data interpretation. This technique works well in the presence of murky water and other obstructions to vision. The other is a remote television camera inspection. If viewing conditions are good, this method provides the most unambiguous evidence of leaks. Both of these methods require direct access to the sewer pipe, so the practicality of this access will have to be determined.

All of the possible inspection techniques have the problem that they will not be able to differentiate between holes in the piping that occurred before the system was abandoned in 1979 (that actually caused leaks) and those holes that occurred after that time. 


\subsection{REFERENCES}

Denham, D. H. Undated. Failure of 307 Basin Transfer Line and Resultant Ground Contamination. BNWL-CC-2617, Pacific Northwest Laboratory, Richland, Washington.

Dennison, D. I _ , D. R. Sherwood, and J. S. Young. 1989. Status Report on Remedial Investigation of the 300 Area Process Ponds. PNL-6442, Pacific Northwest Laboratory, Richland, Washington.

DOE (U. S. Department of Energy). 1989a. Draft Remedial Investigation/ Feasibility Study Work Plan for the 300-FF-1 Operable Unit, Hanford Site, Richland, Washington. DOE/RL 88-31, Rev. 2, U.S. Department of Energy, Richland, Washington.

DOE (U. S. Department of Energy). 1989b. Draft Remedial Investigation/ Feasibility Study Work Plan for the 300-FF-5 Operable Unit, Hanford Site, Richland, Washington. DOE/RL 89-14, Draft B, U.S. Department of Energy, Richland, Washington.

Gee, G. W. 1987. Recharge at the Hanford Site: Status Report. PNL-6403, Pacific Northwest Laboratory, Richland, Washington.

Hall, R. B. 1978. Ground Contamination Beneath RW Tee at 340. TC-1040, Hanford Engineering Development Laboratory, Richland, Washington..

Haney, W. A. 1960. Disposal of Radioactive Liquid Wastes from 300 Area Laboratory Facilities. HW-64292, General Electric Hanford Atomic Products Operation, Richland, Washington.

HEDL (Hanford Engineering Development Laboratory). 1977. Unusual Occurrence Report Number 35-77. Hanford Engineering Development Laboratory, Richland, Washington.

Heid, K. R. 1956. Summary of Liquid Radioactive Wastes Discharged to Ground, 300 Areas Through October 1956. HW-47055, General Electric Hanford Atomic Products Operation, Richland, Washington.

ICF Northwest. 1987a. Level 1 Remedial Investigation Work Plan, 300 Area Process Ponds. PNL-7251, prepared by ICF Northwest, A Division of ICF Technology Incorporated, Richland, Washington, for Pacific Northwest Laboratory, Richland, Washington.

ICF Northwest. 1987b. Draft Level 1 Remedial Investigation Work Plan, 316-3 Waste Disposal Trenches. PNL-7252, prepared by ICF Northwest, A Division of ICF Technology Incorporated, Richland, Washington, for Pacific Northwest Laboratory, Richland, Washington. 
PNL (Pacific Northwest Laboratory). 1986. Reportable Event Report, Transfer of Mislabeled Drum of Hazardous Material. RE-86-10, Pacific Northwest Laboratory, Richland, Washington.

Schalla, R., R. L. Aaberg, D. J. Bates, J. V. M. Carlile, M. D. Freshley, T. L. Liikala, P. J. Mitchell, K. B. Olsen, and J. T. Rieger. $1988 \mathrm{a}$. Revised Ground-Water Monitoring Compl iance Plan for the 300 Area Process Trenches. PNL-6671, Pacific Northwest Laboratory, Richland, Washington.

Schalla, R., R. W. Wallace, R. L. Aaberg, S. P. Airhart, D. J. Bates, J. M. Carlile, C. S. Cline, D. I-Dennison, M. D. Freshley, P. R. Heller, E. J. Jensen, K. B. Olsen, R. G. Parkhurst, J. T. Rieger, and E. J. Westergard. 1988b. Interim Characterization Report for the 300 Area Process Trenches. PNL-6716, Pacific Northwest Laboratory, Richland, Washington.

Stenner, R. D., K. H. Cramer, K. A. Higley, S. J. Jette, D. A. Lamar, T. J. McLaughlin, D. R. Sherwood, and N. C. Van Houten. 1988. Hazard Ranking System Evaluation of CERCLA Inactive Waste Sites at Hanford. PNL-6456, 3 vols., Pacific Northwest Laboratory, Richland, Washington.

Tri-Party Agreement. 1989. Hanford Federal Facility Agreement and Consent Order Between the U.S. Environmental Protection Agency, the U.S. Department of Energy, and the State of Washington Department of Ecology, May 15, 1989. U.S. Department of Energy, Richland Operations Office, Richland, Washington. 
APPENDIX

\section{LETTERS}


Letter 1. PROCESS POND

\title{
Hanford Engineering Development Laboratory
}

\author{
To: G. D. Carpenter \\ C6: Fie'Gices \\ 11. A. FEES \\ W. $\therefore<\angle T S$
}

\section{PURPOSES}

To develop analytical techniques which will be used later.

- To evaluate the surface contamination, both chemical and radioactive to permit preliminary planning toward pond decommissioning.

- To confirm and evaluate cobalt-60 contamination revealed by ARMS survey.

- To compare analyses with 1970 sample from North Process Pond.

\section{SAMPLES}

- Obtain a larger number of samples than we expect to analyze (about 50 total).

- Sample 12 to 15 locations geographically well distributed.

- Sample surface and at 1 foot depth intervals as deep as possible with simple digging tools. Post hole digger or spade.

- Each sample should be more than 1 pint but less than 1 quart.

- Label each sample carefully. Location, depth, date, person who took sample and GM reading on sample carton.

\section{ANALYSES}

Group 1 (Whole Pond Area) - 10 sample sites - 30 samples

1. Approximate density of samples as received $(g / m \mathbf{l})$ and after drying.

2. Chemical analysis for copper and uranium ( $\mathrm{mg} / \mathrm{g}$ dry)

3. Radiochemical analysis for cobalt $-60(\mu \mathrm{Ci} / \mathrm{g}$ dry $)$ and try to identify other gamma emitters.

- Group 2 (Three Settling Bays) - 5 sample sites - 15 samples

1. Chemical ana y $_{j}$ is for fluoride ion and hexavalent chromium.

2. Radiochemical analysis for uranium nuclides and protactinium-234m.

3. Possible quantitative measurement of gama emitiers.

- Group 3 (First Bay) - 2 or 3 sample sites - up to 6 samples

1. Chemical analysis for toxic metals - mercury, beryllium, silver, nickel, lead, cadmium and zinc. 


\section{Letter $1 . \quad$ (contd)}

G. D. Carpenter

2. Radiochemical analyses

a) Try to identify alpha emitters, especially plutonium nuclides and thorium nuclides.

b) Try to identify beta emitters, especially strontium-90 and promethium-147.

Attachment - 1970 analyses from North Pond. 
Letter 1. (contd)

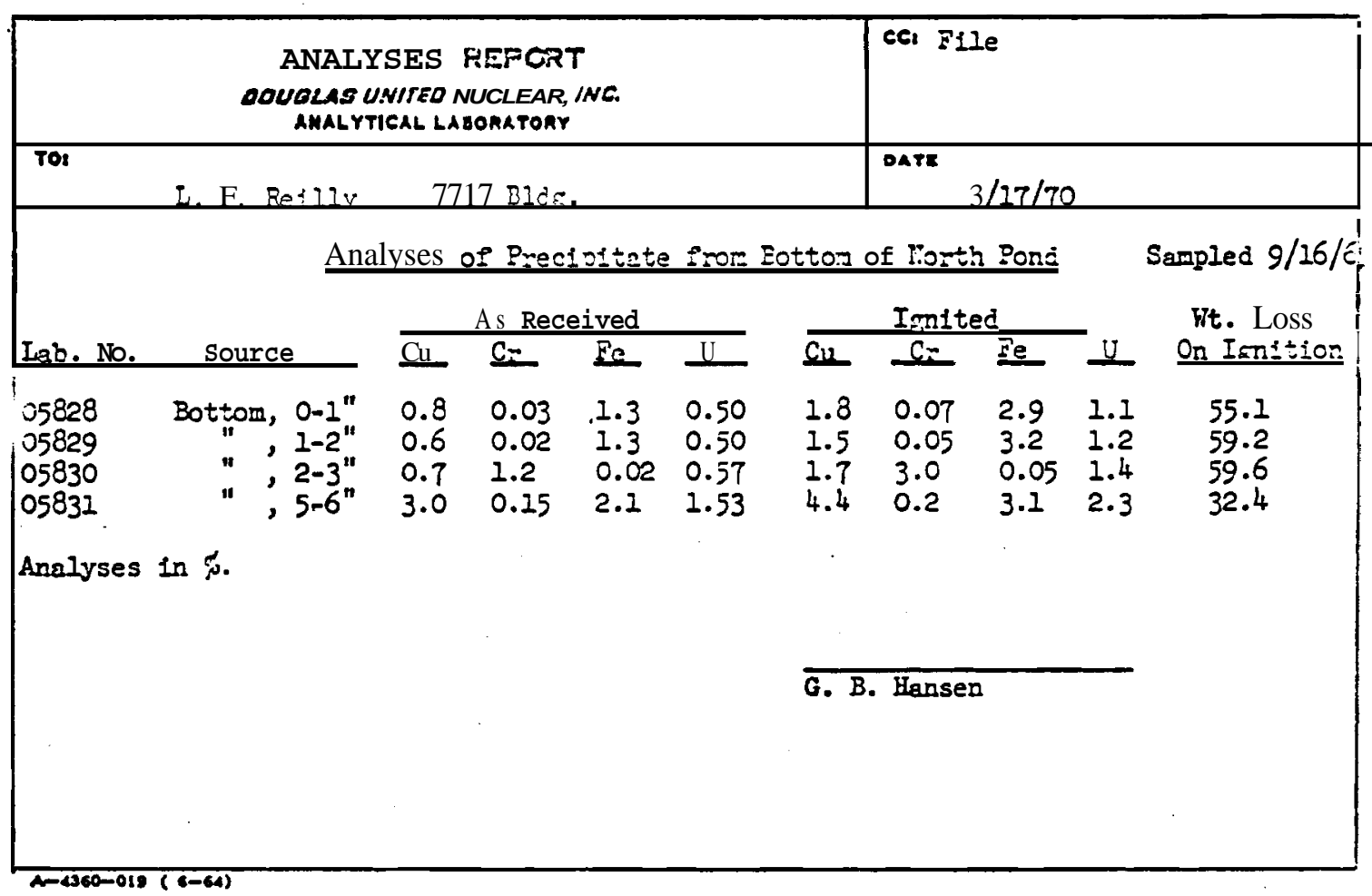

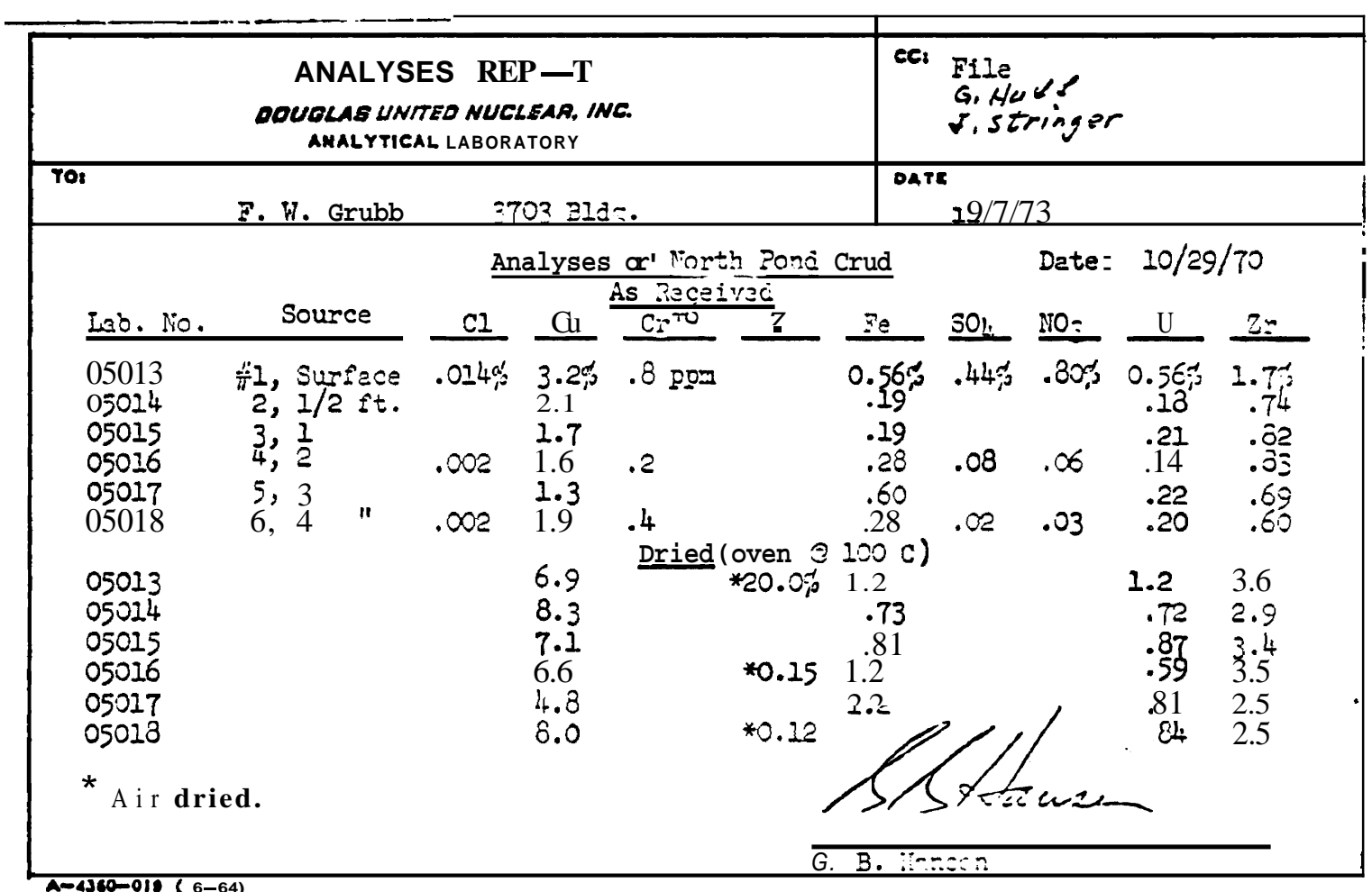




\title{
Letter 2.
}

Operated by

Westinghouse

Hanford Company

Prom: . Applied Chemistry and Analysis

Doto: July 22, 1974

subiect: SOUTH PROCESS POND SOIL SAMPLE ANALYSES AND ESTIMATED FUTURE COSTS

\section{Hanford Engineering Development Laboratory}

TO: R. B. Hall

\author{
cC: GJ Alkire \\ RL Moore \\ RW Stromatt \\ BP Van der Cook
}

A summary of the methods used and estimated future costs to analyze the South Process Pond Soil Samples and the results of the analyses follow. Attached is a Spark Source Mass Spectrographic analyses of two of the samples.

Now that we have run these samples, we can make a better estimate of costs using the procedures outlined and assuming 10 samples or more. Cost per determination for elements run by flame AAS will be about $\$ 10$; for elements by flameless AAS, about $\$ 20$; for elements (U specifically) by spectrophotometry, about $\$ 20 ;$ and $F$, about $\$ 30$. Sample preparation will cost $\$ 25$ per sample in units of 10 or $\$ 15$ per sample in units of 20.

Leach Procedure. Samples weighing 10 grams excluding rocks were treated with $100 \mathrm{ml}_{2} \mathrm{~N} \mathrm{HNO}_{3}$ at a temperature just below boiling for 4 hours. Samples 2, 3, 4 ana 9 did not undergo complete reaction and were treated with an additional $20 \mathrm{ml}$ concentrated $\mathrm{HNO}_{3}$. The solutions were diluted back to $100 \mathrm{ml}$ and stored in plastic bottles until analyzed.

TABLE 1. Surmary of Analytical Procedures

\begin{tabular}{|c|c|c|c|}
\hline Constituent & Method & Special Conditions & Spike Recovery, \% \\
\hline $\mathrm{Hg}$ & Flameless AAS ${ }^{*}$ & $\begin{array}{l}\text { Di iuted sample treated } \\
\text { with } \mathrm{H}_{2} \mathrm{SO}_{4} \text { and } \mathrm{KMnO}_{4}\end{array}$ & \\
\hline ar & Flame AAS & $\begin{array}{l}\mathrm{La}\left(\mathrm{NO}_{3}\right)_{3} \text { and concentrated } \\
\mathrm{HNO}_{3} \text { added to diluted } \\
\text { solution to minimize } \\
\text { matrix effects }\end{array}$ & $99-120$ \\
\hline $\mathrm{Ni}$ & Flame AAS & & $104-123$ \\
\hline $\operatorname{Cr}(V I) * *$ & Spectrophotomet ric & & 0 \\
\hline Total $\mathrm{Cr}$ & Flame AAS & Same as for $\mathrm{Cu}$ & $76-90$ \\
\hline
\end{tabular}




\section{Letter 2. (contd)}

R. B. Hall

$\frac{\text { Constituen }}{\mathrm{Zn}}$

cd

$\mathrm{Ag}$

$\mathrm{Pb}$

$\mathrm{Be}$

U

F

Density
Flameless AAS

Flame AAS

$\frac{\text { M }}{\text { Flame AAS }}$

Flame AAS

Flame AAS

Flameless AAS

Spectrophotometric $\star \star \star$

Pyrohydrolysi s and Specific Ion Electrode Potentiometry

Weight of a Pour Volume
2

July 22, 1974

Spike Recovery, :

96-103

Concentrated $\mathrm{HNO}_{3}$ ad
to diluted solution.

Background correction

required for the instrument.

Graphite furnace with background correction: 0-50 ppb.

Concentrated $\mathrm{HiNO}_{3}$ adied to sample and no background correction: $0-2$ ppm.

Concentrated $\mathrm{HNO}_{3}$ added 98-110

to diluted sample

91-95

Carbon rod atomization

Separation by soluent extraction with hexone.

Thiocyarate reagent used to develop color in organic phase.

Separation of $F$ from sample by pyrohydrolysis

at $1000^{\circ} \mathrm{C}$ using $\mathrm{WC}_{3}$ as

an accelerator. TISAB

buffering solution added

to the F catch solution prior to measurement.

As received samples not dried. Dried samples dried at $105^{\circ} \mathrm{C}$ overnight.

98-101 
TABLE 2. Rasults of Analysis of South Process Pond Soil Samples

\begin{tabular}{|c|c|c|c|c|c|c|c|c|c|c|c|c|c|}
\hline \multirow[b]{2}{*}{ Sample } & \multicolumn{2}{|c|}{ Density, $\mathrm{g} / \mathrm{ml}$} & \multicolumn{11}{|c|}{ Constituents, $\mathrm{kg} / \mathrm{g}$} \\
\hline & As Received & Dried & $\mathrm{Hg}$ & $\mathrm{Cu}$ & $\mathrm{Ni}$ & $\mathrm{Cr}$ & $\underline{z n}$ & Cd & $\mathrm{Ag}$ & $\underline{\mathrm{Pb}}$ & $\mathrm{Be}$ & $U$ & $F$ \\
\hline Blank & 1.36 & 1.34 & $<0.5$ & 9 & 3 & 20 & 30 & $<0.5$ & $\sim 0.3$ & 8 & 0.27 & $<50$. & 270 \\
\hline $1 A$ & 1.36 & 1.32 & 4 & 25000 & 970 & 230 & 320 & 5 & 5 & 170 & 2.7 & 3900 & 2200 \\
\hline $2 A$ & 0.45 & 0.37 & 5 & 87000 & 3100 & 190 & 420 & 9 & 44 & 230 & 3.5 & 6000 & 16000 \\
\hline $2 \mathrm{~B}$ & 0.97 & 0.94 & $\sim 0.3$ & 19000 & 580 & 8 & 110 & 3 & 36 & 80 & 2.1 & 1500 & 7200 \\
\hline $3 A$ & 0.53 & 0.46 & 8 & 7,9000 & 2400 & 410 & 550 & 9 & 74 & 300 & 4.9 & 7200 & 3700 \\
\hline $3 B$ & 0.92 & 0.87 & 20.5 & 20000 & 580 & 200 & 180 & 3 & 38 & 100 & 2.4 & 1800 & 2900 \\
\hline $4 A$ & 0.4 & 0.28 & 16 & 74000 & 2300 & 390 & 630 & 12 & 349 & 380 & 6.1 & 7600 & 4900 \\
\hline $5 A$ & 1.06 & 1.00 & 6 & 30000 & 1200 & 180 & 390 & 6 & 85 & 220 & 2.4 & 3300 & 3300 \\
\hline $6 A$ & 1.16 & 1.12 & 8 & $2_{2} 3000$ & 1100 & 150 & 490 & 6 & 102 & 230 & 2.2 & 3000 & 1100 \\
\hline $7 \mathrm{~A}$ & 0.47 & 0.36 & 14 & 74000 & 1000 & 140 & 720 & 10 & 162 & 310 & .5 .2 & 3300 & 3000 \\
\hline $8 \mathrm{~A}$ & 1.31 & 1.28 & $<0.5$ & 880 & 93 & 20 & 40 & $<0.5$ & 13 & 20 & 0.25 & 130 & 750 \\
\hline $9 A$ & 0.84 & 0.76 & 13 & 44000 & 1800 & 540 & 770 & 13 & 338 & 390 & 3.6 & 5400 & 1800 \\
\hline $10 \mathrm{~A}$ & 1.26 & 1.24 & $<0.5$ & 850 & 170 & 80 & 50 & 1 & 15 & 40 & 0.29 & 130 & 560 \\
\hline $11 \mathrm{~A}$ & 1.23 & 1.20 & 4 & 12000 & 380 & 170 & 260 & 5 & 65 & 90 & 3.0 & 790 & 560 \\
\hline $12 \mathrm{~A}$ & 1.59 & 1.57 & $<0.5$ & 250 & 28 & 10 & 30 & $<0.5$ & 3 & 10 & 0.3 & 50 & 500 \\
\hline $13 A$ & 1.45 & 1.43 & 1 & 4000 & 150 & 90 & 120 & 2 & 25 & 30 & 1.2 & 230 & 410 \\
\hline $14 \mathrm{~A}$ & 1.75 & 1.73 & $<0.5$ & 390 & 33 & 10 & 20 & $<0.5$ & 2 & 7 & 0.22 & $<50$ & 370 \\
\hline $15 \mathrm{~A}$ & 1.69 & 1.67 & $<0.5$ & 770 & 52 & 10 & 40 & 0.6 & 5 & 8 & 0.32 & $<50$ & 310 \\
\hline
\end{tabular}




\section{Letter 2. (contd)}

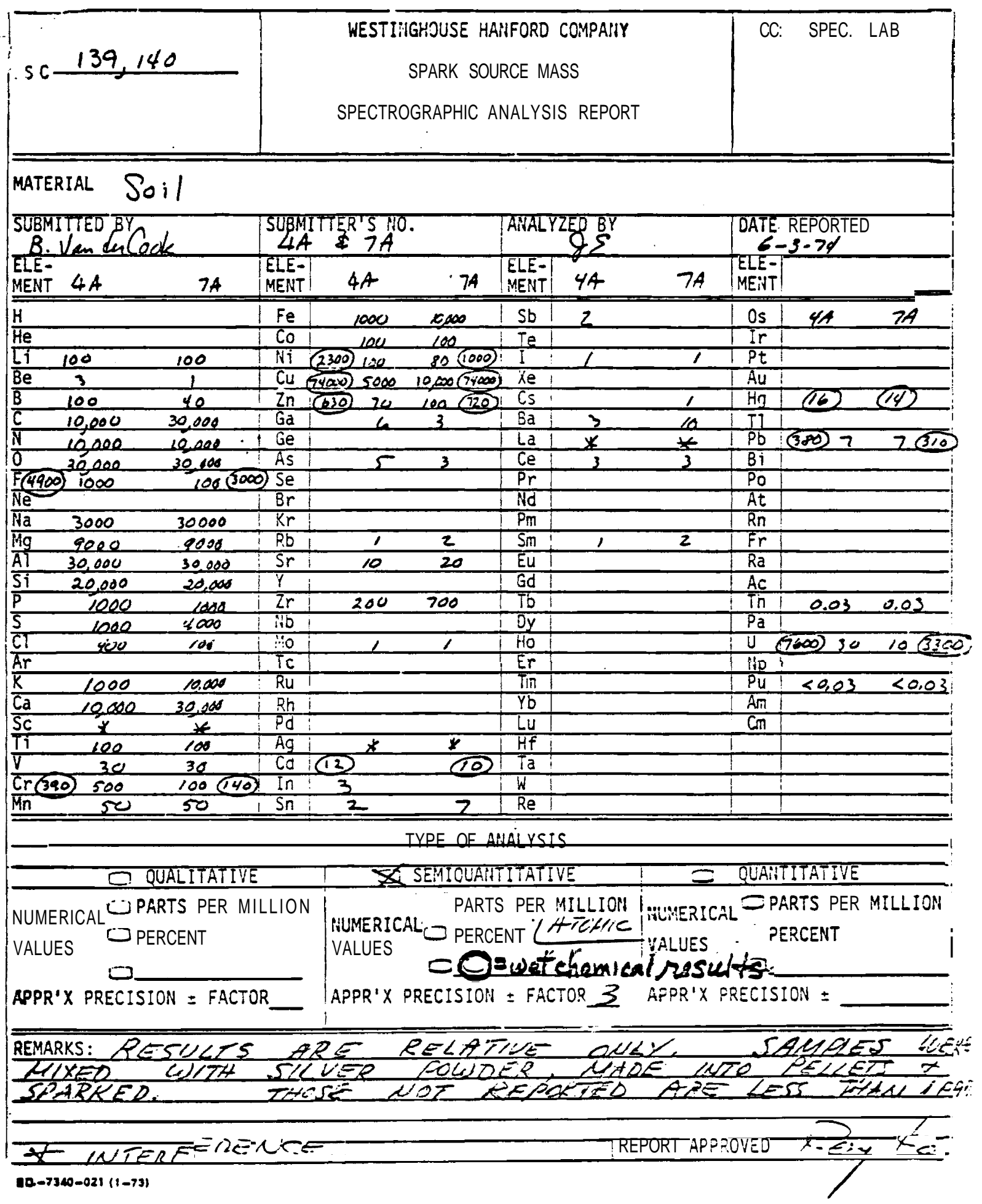


Letter 2. (contd)

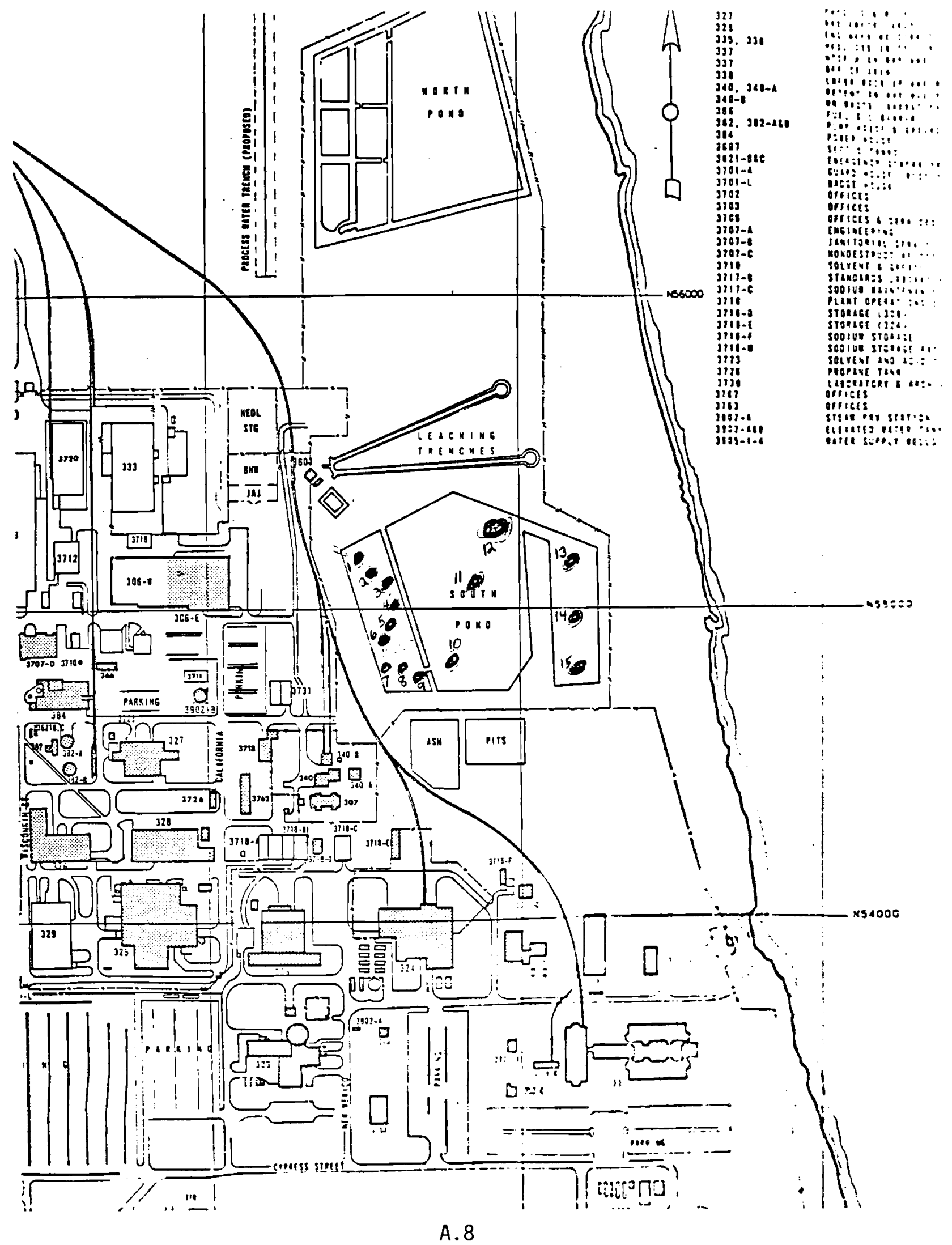




\section{Letter 3.}

From: Applied Chemistry and Analysis

Phone: 2-3805

Date: December 31, 1975

Subject: ANALYTICAL CُHEMISIRY RESULTS FOR ACD AND FILTER

BACKWASH LEACHES OF EAST TRENCH SOUTHPROCESS POND SOIL SAMPES

To: R.B. Hall

$$
\begin{aligned}
& \text { cc: G. J. Alkire } \\
& \text { R. L. Moore } \\
& \text { RWS/File } \\
& \text { /LB }
\end{aligned}
$$

\section{Hanford Engineering Development Laboratory}

In these analyses 10 gram samples (excluding rocks) were equi librated with, $100 \mathrm{ml}$ leach solutions 4 hrs. $2 M$ HN0, just below the boiling temperature was used for the acid leach,-and a 315 building backwash sample (taken on 12/19/75 from No. 2 filter) was used for the backwash solution leach. The backwash solution was equilibrated with the samples on a mechanical shaker.

The analytical procedures used were the same as used for the South Pond soil samples analyzed in July 1974.

The results are tabulated on the following attachment.

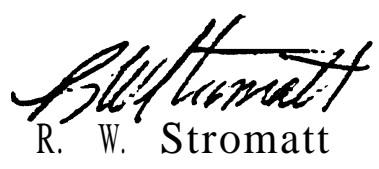

eld

$\underline{\text { Attachment }}$ 
Letter $3 . \quad$ (contd)

\begin{tabular}{|c|c|c|c|c|c|c|}
\hline $\begin{array}{l}\text { Lab } \\
\text { No. }\end{array}$ & $\begin{array}{c}\text { Sample } \\
\text { No. } \\
\end{array}$ & $\begin{array}{l}\text { Leach } \\
\text { Solution }\end{array}$ & $\begin{array}{c}\mathrm{Pb} \\
\mu \mathrm{g} / \mathrm{g}\end{array}$ & $\begin{array}{c}\mathrm{Cu} \\
\underline{\mu g} / \mathrm{g}\end{array}$ & $\begin{array}{c}U \\
\mu g / g\end{array}$ & $\begin{array}{l}\mathrm{Co}-60 \\
\mu \mathrm{Ci} / \mathrm{g}\end{array}$ \\
\hline 3344 & 1 & $\begin{array}{l}\text { Acid } \\
\text { Backwash }\end{array}$ & $\begin{array}{l}26 \\
<2\end{array}$ & $\begin{array}{c}2900 \\
3.5\end{array}$ & $\begin{array}{r}280 \\
<100\end{array}$ & $\begin{array}{r}4.8 \times 10^{-5} \\
<1.7 \times 10^{-5}\end{array}$ \\
\hline 3345 & 2 & $\begin{array}{l}\text { Acid } \\
\text { Backwash }\end{array}$ & $\begin{array}{l}4.8 \\
<2\end{array}$ & $\begin{array}{c}7800 \\
9.7\end{array}$ & $\begin{array}{r}390 \\
<100\end{array}$ & $\begin{array}{r}1.3 \times 10^{-4} \\
<1.7 \times 10^{-5}\end{array}$ \\
\hline 3346 & $3 a$ & $\begin{array}{l}\text { Acid } \\
\text { Backwash }\end{array}$ & $\begin{array}{l}45 \\
<2\end{array}$ & $\begin{array}{r}5200 \\
13\end{array}$ & $\begin{array}{r}500 \\
<100\end{array}$ & $\begin{array}{r}1.3 \times 10^{-4} \\
<1.7 \times 10^{-5}\end{array}$ \\
\hline 3347 & $3 b$ & $\begin{array}{l}\text { Acid } \\
\text { Backwash }\end{array}$ & $\begin{array}{l}4.5 \\
<2\end{array}$ & $\begin{array}{l}36 \\
<1\end{array}$ & $\begin{array}{l}<100 \\
<100\end{array}$ & $\begin{array}{l}<1.7 \times 10^{-5} \\
<1.7 \times 10^{-5}\end{array}$ \\
\hline 3348 & $3 c$ & $\begin{array}{l}\text { Acid } \\
\text { Backwash }\end{array}$ & $\begin{array}{l}4.6 \\
<2\end{array}$ & $\begin{array}{l}43 \\
<1\end{array}$ & $\begin{array}{l}<100 \\
<100\end{array}$ & $\begin{array}{l}<1.7 \times 10^{-5} \\
<1.7 \times 10^{-5}\end{array}$ \\
\hline 3349 & 4 & $\begin{array}{l}\text { Acid } \\
\text { Backwash }\end{array}$ & $\begin{array}{l}29 \\
<2\end{array}$ & $\begin{array}{r}1400 \\
5.9\end{array}$ & $\begin{array}{r}400 \\
<100\end{array}$ & $\begin{array}{l}<1.7 \times 10^{-5} \\
<1.7 \times 10^{-5}\end{array}$ \\
\hline 3350 & 5 & $\begin{array}{l}\text { Acid } \\
\text { Backwash }\end{array}$ & $\begin{array}{l}16 \\
<2\end{array}$ & $\begin{array}{r}2200 \\
3.2\end{array}$ & $\begin{array}{r}120 \\
<100\end{array}$ & $\begin{array}{r}3.3 \times 10^{-5} \\
<1.7 \times 10^{-5}\end{array}$ \\
\hline 3351 & 6 & $\begin{array}{l}\text { Acid } \\
\text { Backwash }\end{array}$ & $\begin{array}{l}16 \\
<2\end{array}$ & $\begin{array}{r}1700 \\
3.0\end{array}$ & $\begin{array}{l}<100 \\
<100\end{array}$ & $\begin{array}{r}4.7 \times 10^{-5} \\
<1.7 \times 10^{-5}\end{array}$ \\
\hline 3352 & 7 & $\begin{array}{l}\text { Acid } \\
\text { Backwash }\end{array}$ & $\begin{array}{l}63 \\
<2\end{array}$ & $\begin{array}{r}10100 \\
8.9\end{array}$ & $\begin{array}{r}530 \\
<100\end{array}$ & $\begin{array}{r}1.5 \times 10^{-4} \\
<1.7 \times 10^{-5}\end{array}$ \\
\hline 3353 & 8 & $\begin{array}{l}\text { Acid } \\
\text { Backwash }\end{array}$ & $\begin{array}{l}16 \\
<2\end{array}$ & $\begin{array}{l}360 \\
1\end{array}$ & $\begin{array}{r}120 \\
<100\end{array}$ & $\begin{array}{l}<1.7 \times 10^{-5} \\
<1.7 \times 10^{-5}\end{array}$ \\
\hline 3354 & 9 & $\begin{array}{l}\text { Acid } \\
\text { Backwash }\end{array}$ & $\begin{array}{l}16 \\
<2\end{array}$ & $\begin{array}{l}530 \\
1\end{array}$ & $\begin{array}{r}110 \\
<100\end{array}$ & $\begin{array}{l}<1.7 \times 10^{-5} \\
<1.7 \times 10^{-5}\end{array}$ \\
\hline 3355 & 10 & $\begin{array}{l}\text { Acid } \\
\text { Backwash }\end{array}$ & $\begin{array}{l}13 \\
<2\end{array}$ & $\begin{array}{r}2000 \\
2.0\end{array}$ & $\begin{array}{l}<100 \\
<100\end{array}$ & $\begin{array}{r}4.4 \times 10^{-5} \\
<1.7 \times 10^{-5}\end{array}$ \\
\hline 3356 & וו & $\begin{array}{l}\text { Acid } \\
\text { Backwash }\end{array}$ & $\begin{array}{l}17 \\
<2\end{array}$ & $\begin{array}{r}2300 \\
2.2\end{array}$ & $\begin{array}{r}110 \\
<100\end{array}$ & $\begin{array}{r}4.8 \times 10^{-5} \\
<1.7 \times 10^{-5}\end{array}$ \\
\hline 3357 & 12 & $\begin{array}{l}\text { Acid } \\
\text { Backwash }\end{array}$ & $\begin{array}{l}18 \\
<2\end{array}$ & $\begin{array}{l}610 \\
1\end{array}$ & $\begin{array}{r}180 \\
<100\end{array}$ & $\begin{array}{l}<1.7 \times 10^{-5} \\
<1.7 \times 10^{-5} .\end{array}$ \\
\hline 3358 & 13 & $\begin{array}{l}\text { Acid } \\
\text { Backwash }\end{array}$ & $\begin{array}{l}18 \\
<2\end{array}$ & $\begin{array}{l}920 \\
2.2\end{array}$ & $\begin{array}{r}120 \\
<100\end{array}$ & $\begin{array}{l}<1.7 \times 10^{-5} \\
<1.7 \times 10^{-5}\end{array}$ \\
\hline 3359 & 14 & $\begin{array}{l}\text { Acid } \\
\text { Backwash }\end{array}$ & $\begin{array}{l}10 \\
<2\end{array}$ & $\begin{array}{r}1400 \\
1.8\end{array}$ & $\begin{array}{l}<100 \\
<100\end{array}$ & $\begin{array}{r}4.0 \times 10^{-5} \\
<1.7 \times 10^{-5}\end{array}$ \\
\hline 3360 & 15 & $\begin{array}{l}\text { Acid } \\
\text { Backwash }\end{array}$ & $\begin{array}{l}18 \\
<2\end{array}$ & $\begin{array}{r}2400 \\
1.1\end{array}$ & $\begin{array}{r}100 \\
<100\end{array}$ & $\begin{array}{r}6.5 \times 10^{-5} \\
<1.7 \times 10^{-5}\end{array}$ \\
\hline 3361 & 16 & $\begin{array}{l}\text { Acid } \\
\text { backwash }\end{array}$ & $\begin{array}{l}29 \\
<2\end{array}$ & $\begin{array}{r}2800 \\
2.0\end{array}$ & $\begin{array}{r}220 \\
<100\end{array}$ & $\begin{array}{r}5.9 \times 10^{-5} \\
<1.7 \times 10^{-5}\end{array}$ \\
\hline 3362 & 17 & $\begin{array}{l}\text { Acid } \\
\text { Backwash }\end{array}$ & $\begin{array}{l}22 \\
<2\end{array}$ & $\begin{array}{l}750 \\
1.4\end{array}$ & $\begin{array}{r}220 \\
<100\end{array}$ & $\begin{array}{l}<1.7 \times 10^{-5} \\
<1.7 \times 10^{-5}\end{array}$ \\
\hline 3363 & 18 & $\begin{array}{l}\text { Acid } \\
\text { Backwash }\end{array}$ & $\begin{array}{l}20 \\
<2\end{array}$ & $\begin{array}{r}2400 \\
<1\end{array}$ & $\begin{array}{r}100 \\
<100\end{array}$ & $\begin{array}{r}7.6 \times 10^{-5} \\
>1.7 \times 10^{-5}\end{array}$ \\
\hline
\end{tabular}




\section{Letter 3. (contd)}

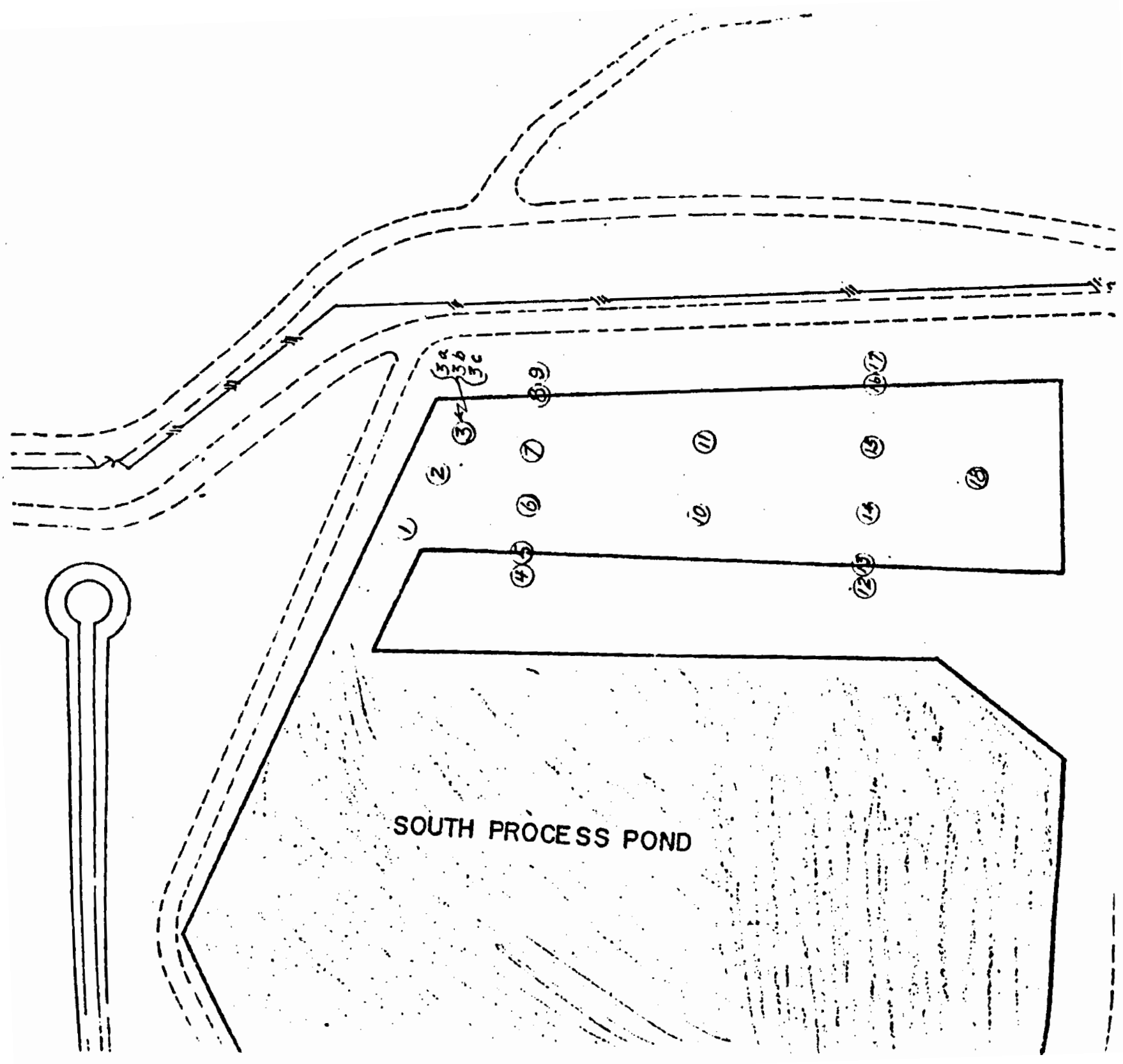




\section{DISTRIBUTION}

No. of

Copies

\section{OFFSITE}

2 DOE/Office of Scientific and Technical Information

C. Cline

Mail Stop PV-11

State of Washington Department of Ecology

Olympia, WA 98504-8711

P. T. Day

U.S. Environmental Protection Agency

Room 178, Federal Building

Richland, 99352

2 D. R. Einan

U.S. Environmental Protection Agency

Room 178, Federal Building

Richland, 99352

2 L. Goldstein

Mail Stop PV-11

State of Washington Department of Ecology

Olympia, WA 98504-8711

\section{ONSITE}

5 DOE Richland Operations Office

J. J. Broderick

R. D. Freeberg

J. D. Goodenough

R. K. Stewart

M. L. Thompson

22 Westinghouse Hanford Company

M. R. Adams

D. L. Armstrong
No. of

Copies
K. R. Fecht
E. M. Greager
W. F. Heine
L. C. Hulstrom (15)
W. L. Johnson
T. M. Wintczak

41 Pacific Northwest Laboratory

C. A. Brandt

P. Cauley

M. A. Chamness

P. G. Doctor

R. M. Ecker

J. W. Falco

M. D. Freshley

J. S. Fruchter

R. M. Fruland

R. E. Gephart

C. S. Glantz

J. M. Hales

P. C. Hays

B. V. Johnston

D. A. Kane

R. R. LaBarge

G. V. Last (2)

K. B. Olsen

W. T. Pennell

L. E. Rogers

R. Schalla

R. L. Skaggs

R. M. Smith

S. S. Teel

R. K. Woodruff

J. S. Young (5)

Publishing Coordination

Technical Report Files (5) 